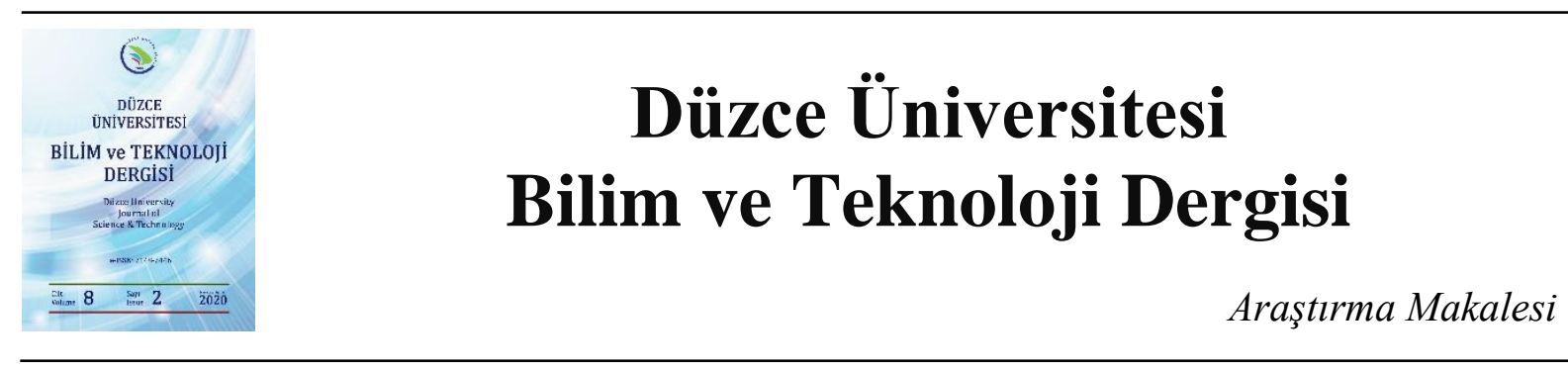

\title{
Derece Zaman Ve Sicaklık Analizine Göre Düzce İlinde Binalar İçin İzolasyon Malzemesinin Tasarım Metodolojisi
}

\author{
Yaşar ŞEN ${ }^{a, *}$ \\ ${ }^{a}$ Biyomedikal Mühendisliği Bölümü, Mühendislik Fakültesi, Düzce Üniversitesi, Düzce, TÜRKIYE \\ * Sorumlu yazarın e-posta adresi: yasarsen@duzce.edu.tr \\ DOI : 10.29130/dubited.650853
}

\begin{abstract}
ÖZET
Yapılardaki enerji tasarrufunu sağlamak ve konfor şartlarını yerine getirmek için en uygun yöntemlerden birisi de izolasyon yapılmasıdır. Bu çalışmada binalarda izolasyon yapılması için, farklı izolasyon malzemeleri ve duvar tipleri için optimum izolasyon kalınlığı analiz edilmiştir. Bu analizlerde kullanılmak üzere gerekli saatlik sıcaklık verileri Düzce ili için 2007-2017 yılları arası Meteoroloji Genel Müdürlüğü (MGM) istasyonundan temin edilmiş ve temin edilen bu verilerde hesaplamada hataya neden olacak değerlerler ayıklanmıştır. Bunun nedeni MGM istasyondan elde edilen verilerde, saatlik sıcaklık verileri arasındaki değerlerin kayıtları hatalı elde edilmiştir. $15{ }^{\circ} \mathrm{C}$ ssıtma, $22{ }^{\circ} \mathrm{C}$ soğutma değerlerinde denge sıcaklıkları için derece saat ve gün hesaplamaları yapılmıştır. Bulunan derece gün değeri ile tuğla ve gaz beton duvarlar için taş yünü, EPS ve XPS izolasyon malzemeleri kullanarak, izolasyon kalınlığı hesabı yapılmış ısıtma maliyeti, tasarruf miktarı ve maliyetin kendini amorti etme süreci dikkate alınarak Düzce ili şartları için en uygun izolasyon malzemesi seçimi yapılmıştır. Sekiz farklı izolasyona sahip bina tipi için TS 825 standartlarına göre özgül ısı kaybı ve yıllık 1sıtma enerji ihtiyacı hesaplanmış ve en uygun izolasyon malzemesinin $20 \mathrm{~kg} / \mathrm{m}^{3}$ EPS olduğu tespit edilmiştir. Gaz betonlu duvarlarda $0,0185 \mathrm{~m}-0,0247 \mathrm{~m}$ arasında değişen optimum kalınlığa sahip izolasyon yapıldığında, \%43,01 ile \%48,54 oranlarında enerji tasarrufu sağlanacaktır. Aynı zamanda dış yüzeye bakan kolon-kiriş bölümleri de izole edileceğinden ve enerji tasarrufu daha da artacağından dolayı gaz beton duvar kullanılsa bile izolasyon yapılması tavsiye edilmektedir.
\end{abstract}

Anahtar Kelimeler: Düzce, Derece-zaman, Derece-gün, Derece-saat İklim verileri,

\section{Design Methodology Of Insulation Material For Buildings In Duzce Province According To Degree-Time And Temperature Analysis}

\begin{abstract}
One of the most suitable methods to save energy in buildings and to meet comfort conditions is insulation. In this study, the optimum insulation thickness for different insulation materials and wall types was analyzed for insulation in buildings. Hourly temperature data required for these analyzes were obtained from the General Directorate of Meteorology (MGM) station between 2007 and 2017 for Düzce and improved these data by extracted errors. Because the data is obtained from the MGM station record the values between the hourly temperature data incorrectly. Degree hour and day calculations were made for equilibrium temperatures at $15^{\circ}$ $\mathrm{C}$ heating and $22^{\circ} \mathrm{C}$ cooling values. The most suitable insulation material was chosen for the conditions; brick and gas concrete walls combined stone wool, obtained degree day value, EPS and XPS insulation materials, cost and saving with self-amortization, of Düzce city. Specific heat loss and annual heating energy need were calculated according to TS 825 standards for the building type having eight different insulation types and found
\end{abstract}

Geliș: 25/11/2019, Düzeltme: 05/02/2020, Kabul: 20/04/2020 
the most suitable insulation material is $20 \mathrm{~kg} / \mathrm{m}^{3} \mathrm{EPS}$. When insulation with optimum thickness varying between $0.0185 \mathrm{~m}-0.0247 \mathrm{~m}$ on gas concrete walls, Energy savings of $43.01 \%$ to $48.54 \%$ will be achieved. At the same time, it is recommended to insulate even if a gas concrete wall is used, since the column-beam sections facing the outer surface will be isolated and energy saving will increase even more.

Keywords: Duzce, Degree-time, Degree-day, Degree-hour Climate data

\section{GÍRIS}

Konfor; fiziksel yönden insanın içinde olduğu şartlarda, minimum enerji harcayarak, maksimum memnuniyet duymasıdır [1]. Göreceli bir kavram olup ve koşullara göre memnuniyet özellikleri göstermektedirler. ISO 7730 Uluslararası Standart da göre 1sıl konforla ilgili olarak minimum \% 80 kullanıcının memnuniyetini öngörmekte [2]. Konfor şartlarını göz önünde bulundururken dikkat etmemiz gereken bir diğer konuda enerji verimliliğidir. Binalar, enerjinin kullanımında önemli yer tutar. Dünyadaki enerjinin \%40’1 binalar da tüketilmektedir. Türkiye'de bu rakam toplam enerjinin \%25-30'una eşittir. Binalarda bu enerjinin \%85'i isınma maksadı ile harcanmaktadır [3]. Enerjinin kullanımı, verimliliği ve üretimi önemli bir konudur. Enerji kullanımının sonucunda açığa çıkan karbon dioksit $\left(\mathrm{CO}_{2}\right)$ İklim değişikliğine ve küresel 1sınmayı oluşturmaktadır. Bundan dolayı enerji tüketimi bilinçli ve tasarruflu yapılmalıdır [4]. Enerji tasarruflu 1sıtma ve soğutma sistemleri binaların duvar taban ve tavandan yalitılması pencereden kaybedilen isının en aza indirilmesi konularında sürekli çalışmalar yapılmakta ve gelişim gösterilmektedir. Bu çalışmalarda kullanılan en önemli etken hiç şüphesiz ki dış hava sıcaklığı olmaktadır. Isıtma, soğutma ve iklimlendirme sistemlerinin performansları farklı oranlarda olsa da atmosfer havası şartlarına bağlıdır. Sistemlerin tasarım ve performans simülasyonları yapılırken, uzun bir zamanın iklim değerleri kullanılmalıdır. Elde edilen sonuçlar gelecek zamanlar için önemli yer tutar. Dolayısıyla ihtiyaç duyulan enerji analizleri ancak iklim verileri dikkate alındığında yakınsamaktadır [5-6]. En eski yöntemlerden biri olan Derece-zaman (derece- gün ve derece- saat) yöntemi binalarda enerji verimliliği analizlerinde halen kullanılmaktadır. Her ülke derece-gün bölgelerini belirleyerek farklı soğutma, 1sıtma ve izolasyon uygulamalarında kullanılmaktadır [7-8]. Eğer bir binanın 1sı kazançları, iç ortam sıcaklığı sabit ise ve ayrıca 1sıtma ve soğutma sistemleri sezon boyunca devamlı olarak çalışıyorsa derece-gün yönteminden elde edilen değerlerle, yıllık ısıtma ve soğutma yükleri iyi bir hassasiyet ile tahmin edilebilir. Derece-gün değerleri ile hesaplanan 1sıtma enerjisi ihtiyacı seçilen "denge noktası sıcaklığı" (Tden)'e bağlıdır. Denge noktası sıcaklığı binalar arasında farklılık gösterebilir. Farklılıklar tasarlanan iç ortam sıcaklığına ve binanın 1sıl özelliklerine bağlı olarak kullanım şekline göre belirlenebilir. Dış ortam sıcaklığı, yapılarda 1sıtmaya veya soğutmaya ihtiyaç olmadığı zamanlardaki denge noktası olarak tanımlanabilir [9]. Enerji verimliliğinin önemi son yıllarda giderek arttığından bu konularda yapılmış birçok çalışma mevcuttur. Bu çalışmalardan bazılarını aşağıdaki gibi sıralayabiliriz. Aynı yapı malzemeleri ile yapılmış ve aynı sıcaklıktaki 4 ortam oluşturulup bu ortamlar izolasyonsız ve farklı türden izolasyon malzemeleriyle (EPS, XPS, Taş yünü) yalıtılmış halde iken ölçümler yaparak en ideal izolasyon malzemesini belirlemeye çalışılmıştır. Yapılan ölçümler sonucunda iç ortam duvar yüzeyi sıcaklıklarını taş yünü için 9-12 ${ }^{\circ} \mathrm{C}$, XPS izolasyon malzemesi için $13-15{ }^{\circ} \mathrm{C}$ ve EPS izolasyon malzemesi için ise $15-17{ }^{\circ} \mathrm{C}$ olarak bulunmuştur. Bu sonuçlara dayanarak en uygun izolasyon malzemesinin taş yünü olduğunu belirlenmiş ve izolasyon malzemelerinin enerji tasarrufundan dolayi geri ödeme sürelerini karşılaştırdığında ise taş yünü için 1,07 yıl, XPS izolasyon malzemesi için 0,73 y1l ve EPS izolasyon malzemesi için ise 0,62 yıl olarak belirtilmiştir [10]. İzmir, Eskişehir, Erzurum ve Bursa illeri seçilerek değişik derece gün bölgeleri için optimum izolasyon kalınlığ hesabı yapılmıştır. Yapılan hesaplamalarda değerlendirme maliyet açısından yapmış ve bu yüzden geri ödeme sürelerini baz alınmıştır. Dış duvar için yapılan hesaplamada optimum izolasyon kalınlıkları bu iller için sırasılyla $0.033,0.061,0.080$ ve $0.047 \mathrm{~m}$ olarak bulunmuştur. Bu iller için geri ödeme süreleri ise 
sirasıyla 2.82, 2.28, 1.89 ve 1,54 y1l olarak hesap edilmiştir [11]. Değişik derece gün bölgelerini temsil eden Mersin, Bursa, Ankara ve Sivas şehirleri baz alınarak değişik izolasyon materyalleri, değişik yakıt ve değişik duvar türleri için optimum izolasyon kalınlığının belirlenmiş ve her farklı seçenek için emisyon değerleri hesaplamıştır. Derece gün bölgesi olarak birinci bölgeyi temsil eden Mersin şehri için yakıt olarak doğalgaz, kömür, fuel-oil, elektrik kullanılması durumunda optimum izolasyon kalınlıklarını sırasıyla 0,03-0,07, 0,04-0,1, 0,05-0,12, 0,8-0,15 m olarak, ikinci derece gün bölgesinde bulunan Bursa ili için yakıt olarak doğalgaz, kömür, fuel-oil, elektrik kullanılması durumunda optimum izolasyon kalınlıklarını sırasıyla 0,04-0,08, 0,05-0,13, 0,07-0,16, 0,9-0,19 m olarak, üçüncü derece gün bölgesinde bulunan Ankara ili için yakıt olarak doğalgaz, kömür, fuel-oil, elektrik kullanılması durumunda optimum izolasyon kalınlıklarını sırasıly 0,07-0,12, 0,09-0,17, 0,11-0,23, 0,13-0,25 m olarak, dördüncü derece gün bölgesini temsil eden Sivas şehri için yakıt olarak elektrik, kömür, fuel-oil, kullanılması durumunda optimum izolasyon kalınlıklarını sırasıyla 0,06-0,13, 0,09$0,18,0,10-0,20, \mathrm{~m}$ olarak hesaplanmıştır [12]. TS 825'e göre İstanbul, Muğla, Rize ve Diyarbakır şehirleri için referans alınan yapının ısıtma ve soğutma durumlarındaki enerji ihtiyacını hesaplamış ve yoğuşma durumlarını değerlendirerek analiz edilmiştir. Buna göre $\mathrm{m}^{2}$ başına 1sıtma enerji ihtiyaçları, İstanbul için $143 \mathrm{kWh} / \mathrm{m}^{2}$, Diyarbakır için $193 \mathrm{kWh} / \mathrm{m}^{2}$, Rize için $127 \mathrm{kWh} / \mathrm{m}^{2}$ ve Muğla için 150 $\mathrm{kWh} / \mathrm{m}^{2}$ olarak hesaplanmıştır. Yine $\mathrm{m}^{2}$ başına soğutma enerji ihtiyaçları ise, İstanbul için 105 $\mathrm{kWh} / \mathrm{m}^{2}$, Diyarbakır için $173 \mathrm{kWh} / \mathrm{m}^{2}$, Rize için $100 \mathrm{kWh} / \mathrm{m}^{2}$, Muğla için $115 \mathrm{kWh} / \mathrm{m}^{2}$ olarak hesaplanmıştır. Ayrıca yapılara izolasyon iyileştirmesi yapılması durumunda 1sıtma ihtiyacının iller için sırasıyla 35, 56, 33, $57 \mathrm{kWh}$ 'e düştügü gözlemlenmiştir. İzolasyon iyileştirmesi yapılan yapının izolasyonsuz hale göre \%70-73 arasında 1sıtma enerji tasarrufu sağlandığını belirleyip, binanın toplam enerji tüketimini ise aynı iller için sırasıyla 230, 279, 223, $249 \mathrm{kWh}$ olarak hesaplamıştır [13]. Ankara'da $80.000 \mathrm{~m}^{2}$ 'lik bölümünde 1sıtma ihtiyacı olan bir alışveriş merkezinin 1sıtma sistemi üzerinde yaklaşık 3 yıl süren deney ve verilerinden faydalanarak enerji ve ekserji analizi yapılmıştır. Analizler sonucunda, ısıtma sistemi için yapılan enerji analizinde; en düşük verimin eşanjörde, en yüksek verimin kazanda, ekserji analizinde ise bunun tersi bir durum görülmüştür. $\mathrm{Bu}$ sonuçlar neticesinde; bu tür çok amaçlı yapılarda enerji performansının değerlendirilmesinde, ekserji analizinin, enerji analizine göre daha gerçekçi olduğu ve kazanda yapılacak iyileştirmenin sistem performansının arttıracağ belirlenmiştir [14]. Derece saat yönteminde, öncelikle belirli bir denge noktasına göre derece saat değerlerinin tespit edilmesi gerekmektedir. Bunun içinde bir yıl içerisinde toplam 8760 saatlik ölçüm değerlerinin olması gerekir. Denge noktası sıcaklığı, bir binada 1sıtmaya veya soğutmaya ihtiyaç duyulmadığı durumdaki dış ortam sıcaklığıdır. Genelde literatürdeki mühendislik hesaplamalarda, izolasyonsuz bir bina için derece saat değerleri isıtmada $18{ }^{\circ} \mathrm{C}$, soğutmada ise $22^{\circ} \mathrm{C}$ denge sıcaklığ 1 için hesaplanır. Isıtma derece saat (HDD) ve soğutma derece saat (CDD) değerleri aşağıdaki denklem (1) ve denklem (2) ile belirlenir [15]. Binalarda izolasyon kalınlığının artması 1sı kaybı azaltması ile birlikte birim alanı 1sıtmak için gereken enerji ihtiyacı azalır ve toplam maliyet düşer. Fakat izolasyon kalınlığının gereğinden fazla arttırılması izolasyon maliyetini arttırır. Bunun sonucunda yüksek izolasyon maliyeti sebebi ile belli bir noktadan sonra toplam maliyet artmaya başlar. Toplam maliyetin minimum olduğu bu nokta optimum izolasyon kalınlığı değeri olarak ifade edilmektedir [24].

Bu çalışmada Düzce ili için 1sıtma soğutma derece zaman hesaplamaları yapılmış, Düzce ili için Meteoroloji Genel Müdürlüğü (MGM) istasyonundan alınan sıcaklık verilerine dayanarak çıkartılan grafik ve tablolar yorumlanmıştır. Elde edilen derece gün verilerine göre optimum izolasyon kalınlığı hesabı yapılarak 8 farklı bina tipi için uygulamadaki enerji sarfiyatı hesaplanarak karşılaştırmalı olarak yorumlanmıştır.

\section{MATERYAL ve METOT}

Literatürde derece zaman yöntemiyle ilgili olarak üç farklı statik yöntem, derece saat yöntemi, derece gün ve bin yöntemi kullanılmaktadır. Binanın dinamik davranışına göre yapılan hesaplamalarda kullanılan dinamik yöntemlerdir Bu çalışmada Düzce ili için Meteoroloji Genel Müdürlüğü (MGM) istasyonundan 11 yıllık dış hava sıcaklığı verileri temin edilerek ısıtma ve soğutma derece gün 
değerleri hesaplanmıştır. Hesaplamalar için gerekli olan verilerden, doğru sonuç elde edebilmek için hatalı ve eksik olanları, yani saatlik çok bariz sıcaklık farkı olan veriler, bir saat önceki ve bir saat sonraki değerlerin ortalaması dikkate alınarak hatalı veri değerleri düzeltilmiş, Excel Programına yüklenmiştir. Isıtma ve soğutma için farklı referans sıcaklıkları için tablolar ve grafikler oluşturulmuştur. Elde edilen ssıtma ve soğutma derece gün değerleri, tablo ve grafiklerdeki değerler karşılaştırmalı şekilde analiz edilerek değerlendirilmiştir. Sekiz farklı izolasyona sahip bina tipi için TS 825 standartlarına göre özgül 1sı kaybı ve yıllık ısıtma enerji ihtiyacı hesaplanarak karşılaştırmalı olarak yorumlanmış ve tavsiyelerde bulunulmuştur. Düzce ili, fazla sert olmayan nemli Karadeniz iklime sahiptir. Ayrıca Akdeniz ve karasal iklimleri arası geçiş özelliği de göstermektedir. Sıcaklık olarak y1llık ortalama $13,0{ }^{\circ} \mathrm{C}$, y1llık yağışların toplam ortalamas $823,7 \mathrm{~kg} / \mathrm{m}^{2}$, nispi nem ortalaması \%75'dir [10]. Metroloji Genel Müdürlüğünden (MGM) alınan verilere göre, Düzce ili için Tablo 1 'deki değerlere bakıldığında ortalama olarak aylık sıcaklık $22,6{ }^{\circ} \mathrm{C}$ ile temmuz ayında en düşük aylık ortalama sıcaklık ise $3,8^{\circ} \mathrm{C}$ ile ocak ayında gerçekleşmiştir. Yıl boyunca sıcaklık ortalaması ise 13,3 ${ }^{\circ} \mathrm{C}$ olmuştur [16].

Tablo 1. Düzce ili için uzun yıllar aylık sıcaklık ortalaması [11]

\begin{tabular}{|c|c|}
\hline AYLAR & ORTALAMA SICAKLIK $\left({ }^{\circ} C\right)$ \\
\hline OCAK & 3,8 \\
\hline ŞUBAT & 5,8 \\
\hline MART & 7,8 \\
\hline NISAN & 12,3 \\
\hline MAYIS & 16,7 \\
\hline HAZİRAN & 20,6 \\
\hline TEMMUZ & 22,6 \\
\hline AĞUSTOS & 22,4 \\
\hline EYLÜL & 18,8 \\
\hline EKİM & 14,3 \\
\hline KASIM & 9,6 \\
\hline ARALIK & 5,8 \\
\hline YILLIK ORTALAMA SICAKLIK DEĞER & 13,33 \\
\hline
\end{tabular}

Bir bölgede, 1sıtma derece gün (Heating Degree Days- HDD), sayısı ile soğutma derece gün sayıs1 (Cooling Degree Days- CDD)'nın bulunması, 1sıtma ve soğutma sistemi maliyetinin ve kapasitesinin belirlenmesi açısından önemli bir yer tutmaktadır. Ortak bir kullanım oluşturmak ve bu değerlerin birbiriyle mukayese edilmesi için, Denklem (1) ve Denklem (2)'nin kullanılması Eurostat (Avrupa Birliği İstatistik Ofisi) önerilmektedir [18].

$$
\begin{aligned}
& \left.H D D=\left(18{ }^{\circ} \mathrm{C}-T_{m}\right) \times d \quad T_{m} \leq 15^{\circ} \mathrm{C} \text { (ısıtma eşiğ } i\right) \\
& H D D=0 \text { ise } T_{m}>15^{\circ} \mathrm{C} \\
& C C D=\left(T_{m}-22^{\circ} \mathrm{C}\right) \times d \quad T_{m} \leq 22{ }^{\circ} \mathrm{C}(\text { soğutma eşiğ } i) \\
& C D D=0 \text { ise } \quad T_{m}>22^{\circ} \mathrm{C}
\end{aligned}
$$

Denklem (1) ve (2) de $\left(T_{m}\right)$ günlük ortalama sicaklık, $(d)$ gün syısı. Hesaplama günlük bazda yapılır. Daha sonra aylık ve yıllık gün derece toplamları bulunur. Soğutma Gün Dereceleri (CDD): Belirli bir zamanda (gün, ay, yıl) dış ortam sıcaklığını hesaba katarak sıcaklığın şiddetini açıklar. Resmi olarak belirlenmiş bir eşik sicaklık olmamakla birlikte inşaat sektörü enerji yönetim 
pratiklerinde eşik sıcaklık $22^{\circ} \mathrm{C}$ olarak alınır. Buna Isıtma ya da soğutma gün dereceleri toplamının bilinmesi, binaların 1sıtılması ya da soğutulması için gerekli olan enerji gereksiniminin hesaplanması açısından önemlidir. Günlük ortalama sicaklık $15^{\circ} \mathrm{C}$ 'nin üzerinde ise 1 sitma gereksizdir. Isıtma maliyeti yıllık HDD ile doğrudan orantılıdır. Bunun için 1 yıl içindeki yakıt maliyeti Yıllık HDD toplamına bölünerek 1 HDD için ısıtma fiyatı çıkartılır [18]. Isıtma, soğutma değerleri dönemindeki toplam gün sayısı, ısıtma ya da soğutma gerektirmeyen günler, bu sayılara dâhil edilmemektedir [17]. Yapılan çalışmada ısıtma için dış hava sıcaklığının $15^{\circ} \mathrm{C}$ 'den küçük ve eşit olduğu sıcaklıkları, soğutma derece saat için ise $22^{\circ} \mathrm{C}$ 'den büyük ve eşit olduğu sıcaklıkları referans alındı. Isıtma derece zaman hesabı yaptığımız aylar Ocak-Şubat-Mart-Nisan-Ekim-Kasım-Aralık soğutma derece zaman hesabı yaptı̆̆ımız aylar ise Mayıs-Haziran-Temmuz-Ağustos ve Eylül aylarıdır.

Farklı izolasyon malzemeleri için optimum izolasyon kalınlığı ve ssıtma enerji ihtiyacı hesabı yapılırken Düzce şartları için iki farklı duvar tipi seçilmiştir. Bu duvar tipleri Şekil 1'de görüldügü gibi tuğla ve gaz beton duvarlardır.
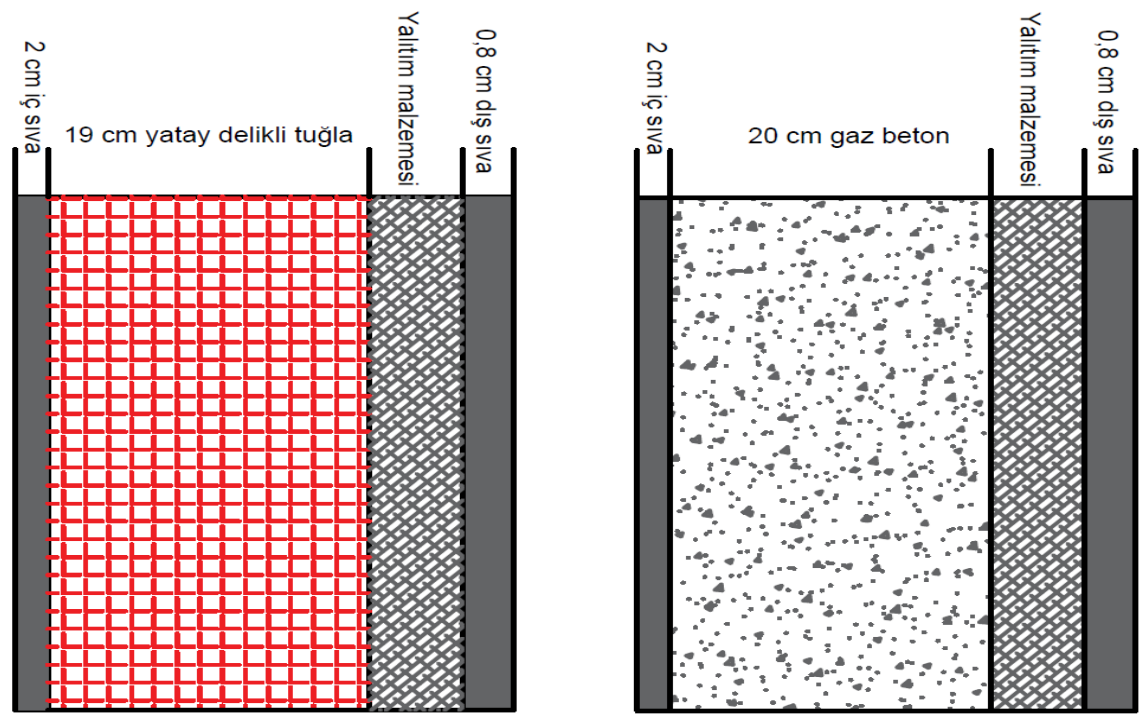

Şekil 1. Hesaplamalarda kullanılan tuğla ve gaz beton duvar

Dış havanın sıcaklığı iç hava sıcaklığından düşük olduğu zaman 1sı kayıpları oluşmaktadır. Aynı şekilde dış havanın sıcaklığı iç hava sıcaklığından fazla olduğu hallerde ise 1sı kazancı meydana gelmektedir.

İç ve diş ortam arasında meydana gelen 1sı kaybi;

$q=U \times\left(T_{b}-T_{0}\right)\left(W / m^{2}\right)$

Formülü ile hesaplanır. Bu formülde $\mathrm{U}$; toplam 1 sı transfer katsayısını, $\mathrm{T}_{\mathrm{b}}$ iç sıcaklığı $\mathrm{T}_{0}$ günlük ortalama dış sıcaklığı vermektedir [18].

Bu formüldeki toplam 1sı transfer katsayısının "U” izolasyonlu bir duvar için eşitlik (4)’teki gibi hesaplanir.

$U=\frac{1}{\frac{1}{h_{i}}+R w+R i n s+\frac{1}{h_{0}}} \quad\left(W / m^{2} K\right)$

Eşitlik (4)'teki " $\mathrm{h}_{\mathrm{i}}$ ” iç hava $1 \mathrm{~S}$ transfer katsayısını, " $\mathrm{h}_{0}$ " dış hava $1 \mathrm{~s} 1$ transfer katsayısını, " $\mathrm{R}_{\mathrm{w}}$ " duvarın toplam is1 direncini, " $R_{\text {ins" }}$ " ise izolasyon malzemesinin termal direncini göstermektedir.

Eşitlik (4)'te kullanılan “ $R_{\text {ins }}$ ” izolasyon malzemesinin termal direnci eşitlik (5)’teki gibi hesaplanır. 
$R_{\text {ins }}=\frac{X}{k}$

Bu eşitlikteki "x" izolasyon malzemesinin kalınlığını "k" ise izolasyon malzemesinin 1sıl iletkenlik katsayısını göstermektedir [22].

Birim alandan kaybedilen 1sı kaybı ise derece gün değerini de kullanarak Eşitlik (6)'daki gibi hesaplanır.

$q_{A}=86400 \times \operatorname{HDD} \times \mathrm{U} \quad\left(J / m^{2} y \iota l\right)$

Bu eşitlikte "HDD" derece gün değerini temsil etmektedir. Yıllık enerji gereksinimi de birin alandan kaybedilen ısının sistemin ısıtma verimine " $\eta$ " bölünmesi ile elde edilmektedir [19].

$E_{A}=\frac{86400 x H D D x U}{\eta} \quad\left(J / m^{2} y l l\right)$

Yapının 1sıtılması için gerekli olan yakıtın yıllık maliyeti Eşitlik (8)'de verilmiştir. Buna göre yıllık 1sıtma maliyeti, yıllık 1sıtma enerji gereksiniminin yakıtın $\mathrm{m}^{3}$ olarak birim maliyeti ile çarpılıp yakıtın alt ısıl değerine bölünmesi ile bulunmaktadır [19].

$C_{A}=\frac{86400 x H D D x U x C_{f}}{\eta x L H V}\left(T L / m^{2} y l l\right)$

Bu eşitlikte " $\mathrm{C}_{\mathrm{f}}$ ” yakıtın maliyetini LHV ise yakıtın alt ısıl değerini göstermektedir.

Yapıların 1sıtma maliyetlerinin toplam değeri belli zaman aralıklarını kapsadığından dolayı günümüz değer faktörü (PWF) değerini bu maliyeti etkileyen faktörlerdendir. Günümüz değer faktörü hesaplanırken enflasyon oranı ( $r$ ), faiz oranı ( i ) ve indirim hızı ( $g$ ) hesaba katılmaktadır. Eşitlik (9), (10) ve (11)'de günümüz değer faktörünün hesaplanma yöntemi gösterilmektedir [19].

Eğer i > g ise;

$r=\frac{i-g}{i+g}$

Eğer $\mathrm{i}<\mathrm{g}$ ise;

$r=\frac{g-i}{1+i}$

$P W F=\frac{(1+r)^{N}-1}{r(1+r)^{N}}$

Eğer i değeri g değerine eşit ise, Eşitlik 11'deki ifade aşağıdaki eşitliğe dönüşür.

$P W F=\frac{1}{1+i}$

Bu çalışmadaki enflasyon oranı ve faiz oranı değerleri sırasıyla \%17,75 ve \%24 olarak [23]'e göre alınmıştır. Eşitlikteki "N" değeri izolasyon malzemesinin kullanım ömrünü vermektedir.

İzolasyon malzemesinin metrekaresinin işçilik dâhil maliyeti ise eşitlik (12)'de verilmiştir.

$C_{\text {ins }}=C_{1} \times \chi \quad\left(T L / m^{2}\right)$ 
Verilen eşitlikte $C_{1}$; izolasyon malzemesinin fiyatını $€ / \mathrm{m}^{3}$ olarak ifade etmektedir. $\mathrm{X}$ ise izolasyon malzemesinin kalınlığını "m" cinsinden ifade etmektedir. İzolasyon malzemesinin maliyetinin eklenmesiyle yıllık 1sıtma maliyeti eşitlik (13)’teki halini almaktadır [19].

$$
C_{t}=\frac{86400 x H D D x C f x P W F x U}{\eta x L H V}+C_{1} x X \quad\left(T L / m^{2} y \iota l\right)
$$

Optimum izolasyon kalınlığı ise yıllık ısıtma maliyetinin izolasyon kalınlığına göre türevi alınarak sıfıra eşitlenmesiyle elde edilmektedir. Eşitlik (14)'de optimum izolasyon kalınlığı ile ilgili formül verilmiştir [20].

$X_{o p t}=\left(\frac{86400 x H D D x C_{f} x P W F x k}{C_{1} x \eta x L H V}\right)^{1 / 2}-k x R_{t w}(m)$

İzolasyon yapıldığından dolayı enerjiden yapılan tasarruf miktarı, izolasyon malzemesinin ömrü de dikkate alınarak eşitlik (15)'de verilmiştir [21].

$$
E S=C_{t o}-C t_{i n s}(T L)
$$

Eşitlikteki " $\mathrm{C}_{\mathrm{to}}$ " binanın izolasyonsuz haldeki toplam 1sıtma maliyetini, " $\mathrm{Ct}_{\text {ins }}$ " ise binanın izolasyonlu haldeki toplama isitma maliyetini ifade etmektedir [21].

Yapılan izolasyon maliyetinin geri ödeme süresi eşitlik (16)'deki gibi hesaplanmaktadır [20].

Geri Ödeme Süresi $=\frac{C_{i n s} x X_{o p t}+C_{a d}}{E S / L T} \quad(y l l)$

\section{VERILERIN ANALIZİ VE DEGERLENDİRM}

\section{A. ISITMA DERECE ZAMAN HESAPLAMALARI İÇIN ANALİ VE DEĞERLENDİRME}

Düzce ili için Meteoroloji Genel Müdürlüğü (MGM) istasyonundan 11 yılın meteorolojik veri seti kullanılmış olup ve elde edilen sıcaklık verilerine göre ortalama sıcaklığ $15^{\circ} \mathrm{C}$ 'nin altında kalan gün sayıları hesaplanarak Şekil 2'de gösterildiği gibi verilmiştir. $15{ }^{\circ} \mathrm{C}$ 'nin altında kalan yani ssıtma ihtiyacı olan gün sayısı en az 164 gün ile 2012 yılında en fazla 213 gün ile 2011 yılında gerçekleşmiştir. Ortalama 1sıtma ihtiyacı bulunan gün sayısı ise 192 gündür.

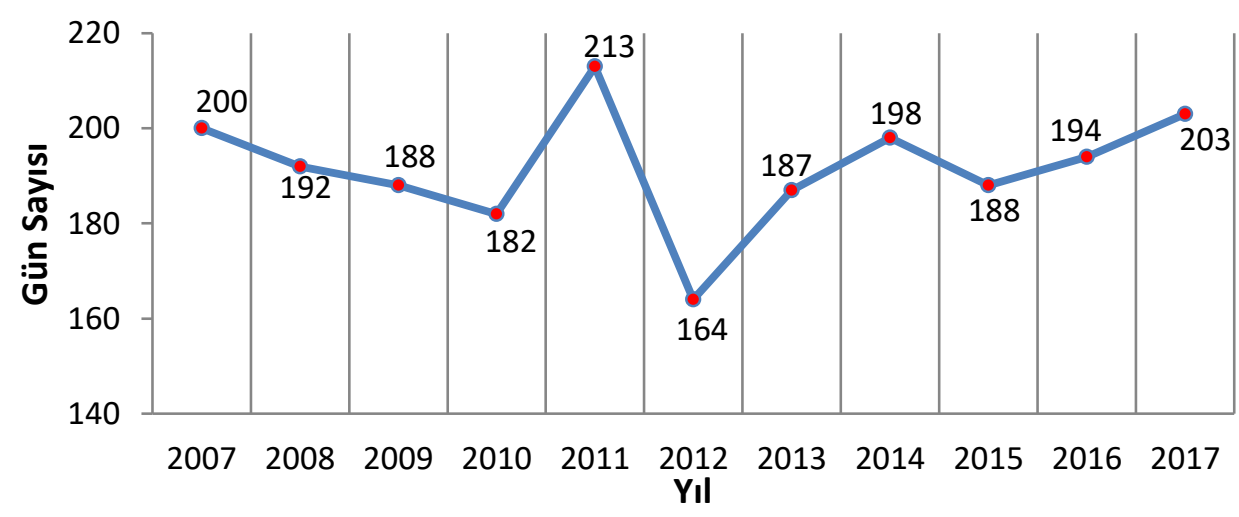

Şekil 2. Ylllara göre ortalama sicaklı̆̆l $15^{\circ} \mathrm{C}$ 'nin altında kalan günleri gösteren grafik 
Aynı zamanda 11 yılın meteorolojik veri kullanılarak yapılan hesaplamalarda $15{ }^{\circ} \mathrm{C}$ denge sıcaklığı için 1sıtma derece gün değerleri Şekil 3 'te gösterildiği gibi verilmiştir. En fazla 1sıtma derece gün değeri 2318 ile 2011 yılında, en az 1sıtma derece gün değeri ise 1620 ile 2010 yılında gerçekleşmiştir. Ayrıca ortalama yıllık 1938 ssıtma derece gün değeri elde edilmiştir.

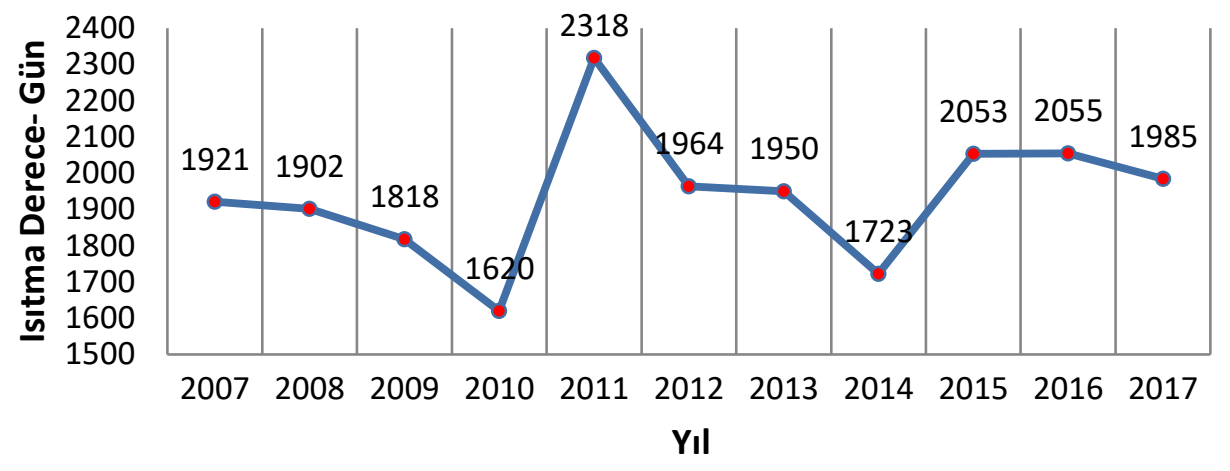

Şekil 3. $15^{\circ} \mathrm{C}$ için ısıtma derece gün değerleri.

Derece gün hesabından sonra mukayese için derece saat hesabı yapılmıștır. Aylık ve y1llık üç farklı denge sıcaklığı saati Şekil 4'te verilmiştir. Bu hesaplama yapılırken meteorolojik veri setinin 11 yıllık veriler aylık olarak ele alınmıştır. Buna göre $5^{\circ} \mathrm{C}$ altı sıcaklıklar 448 ile 13 saat aralığında, ortalaması da 122 saat. $10{ }^{\circ} \mathrm{C}$ altı sicaklıklar 639 ile 121 saat aralığında, otalaması da 249 saat. $15{ }^{\circ} \mathrm{C}$ altı sıcaklıklar 714 ile 407 saat aralığında, ortalaması 348 saat $15{ }^{\circ} \mathrm{C}$ üstü sıcaklıklarda ise 337 ile 30 saat aralığında, ortalama 77 saat olarak elde edilmiştir.

\begin{tabular}{|c|c|c|c|c|c|c|c|c|c|c|c|c|}
\hline \multirow[b]{2}{*}{ AYLAR } & \multirow{2}{*}{$\begin{array}{l}\text { REFERANS } \\
\text { SICAKLIKLAR }\end{array}$} & \multicolumn{11}{|c|}{ YILLAR } \\
\hline & & 2007 & 2008 & 2009 & 2010 & 2011 & 2012 & 2013 & 2014 & 2015 & 2016 & 2017 \\
\hline \multirow{4}{*}{ OCAK } & $5{ }^{\circ} \mathrm{C}$ altı sıcaklık & 413 & 598 & 417 & 346 & 393 & 537 & 363 & 293 & 524 & 530 & 506 \\
\hline & $10^{\circ} \mathrm{C}$ altı sıcaklik & 609 & 714 & 600 & 594 & 700 & 683 & 571 & 584 & 648 & 640 & 685 \\
\hline & $15^{\circ} \mathrm{C}$ altı sıcaklık & 703 & 740 & 692 & 682 & 740 & 739 & 707 & 715 & 708 & 695 & 737 \\
\hline & $15^{\circ} \mathrm{C}$ ve üstü sıcaklık & 41 & 4 & 52 & 62 & 4 & 5 & 37 & 29 & 36 & 49 & 7 \\
\hline \multirow{4}{*}{ ŞUBAT } & $5{ }^{\circ} \mathrm{C}$ altı sıcaklık & 257 & 448 & 286 & 154 & 329 & 532 & 171 & 216 & 308 & 169 & 325 \\
\hline & $10^{\circ} \mathrm{C}$ altı sıcaklık & 529 & 618 & 494 & 382 & 591 & 663 & 464 & 485 & 507 & 407 & 535 \\
\hline & $15^{\circ} \mathrm{C}$ altı sıcaklik & 628 & 665 & 640 & 573 & 649 & 692 & 590 & 603 & 594 & 608 & 620 \\
\hline & $15^{\circ} \mathrm{C}$ ve üstü sıcaklık & 44 & 31 & 32 & 99 & 23 & 4 & 82 & 69 & 78 & 88 & 52 \\
\hline \multirow{4}{*}{ MART } & $5{ }^{\circ} \mathrm{C}$ altı sıcaklık & 128 & 45 & 248 & 144 & 292 & 411 & 156 & 116 & 155 & 117 & 128 \\
\hline & $10^{\circ} \mathrm{C}$ altı sıcaklik & 504 & 364 & 547 & 510 & 503 & 608 & 369 & 448 & 535 & 442 & 484 \\
\hline & $15^{\circ} \mathrm{C}$ altı sıcaklik & 647 & 566 & 651 & 677 & 649 & 677 & 559 & 611 & 681 & 587 & 626 \\
\hline & $15^{\circ} \mathrm{C}$ ve üstü sıcaklık & 97 & 178 & 93 & 67 & 95 & 67 & 185 & 133 & 63 & 157 & 118 \\
\hline \multirow{4}{*}{ NISAN } & $5{ }^{\circ} \mathrm{C}$ altı sıcaklik & 91 & 1 & 28 & 21 & 30 & 22 & 1 & 25 & 155 & 19 & 62 \\
\hline & $10^{\circ} \mathrm{C}$ altı sıcaklık & 372 & 118 & 301 & 215 & 420 & 155 & 242 & 180 & 384 & 152 & 340 \\
\hline & $15^{\circ} \mathrm{C}$ altı sıcaklik & 592 & 382 & 555 & 516 & 631 & 388 & 487 & 463 & 555 & 424 & 521 \\
\hline & $15^{\circ} \mathrm{C}$ ve üstü sıcaklık & 128 & 338 & 165 & 204 & 89 & 332 & 233 & 257 & 165 & 296 & 199 \\
\hline \multirow{4}{*}{ EKIM } & $5{ }^{\circ} \mathrm{C}$ altı sıcaklık & 0 & 0 & 0 & 10 & 48 & 0 & 43 & 15 & 7 & 13 & 3 \\
\hline & $10^{\circ} \mathrm{C}$ altı sıcaklik & 125 & 59 & 28 & 121 & 250 & 29 & 298 & 62 & 67 & 116 & 177 \\
\hline & $15^{\circ} \mathrm{C}$ altı sıcaklik & 339 & 402 & 290 & 449 & 537 & 284 & 547 & 348 & 308 & 478 & 499 \\
\hline & $15^{\circ} \mathrm{C}$ ve üstü sıcaklık & 405 & 342 & 454 & 295 & 207 & 460 & 197 & 396 & 436 & 266 & 245 \\
\hline \multirow{4}{*}{ KASIM } & $5{ }^{\circ} \mathrm{C}$ altı sıcaklık & 148 & 52 & 123 & 34 & 350 & 45 & 72 & 72 & 62 & 217 & 94 \\
\hline & $10^{\circ} \mathrm{C}$ altı sıcaklık & 423 & 308 & 387 & 178 & 643 & 256 & 319 & 411 & 294 & 463 & 397 \\
\hline & $15^{\circ} \mathrm{C}$ altı sıcaklik & 634 & 577 & 636 & 436 & 718 & 603 & 596 & 640 & 570 & 623 & 625 \\
\hline & $15^{\circ} \mathrm{C}$ ve üstü sıcaklık & 86 & 143 & 84 & 284 & 2 & 117 & 124 & 80 & 150 & 97 & 95 \\
\hline \multirow{4}{*}{ ARALIK } & $5{ }^{\circ} \mathrm{C}$ altı sıcaklık & 448 & 338 & 195 & 234 & 370 & 302 & 592 & 200 & 467 & 662 & 268 \\
\hline & $10^{\circ} \mathrm{C}$ altı sıcaklik & 642 & 586 & 504 & 490 & 581 & 588 & 731 & 503 & 711 & 737 & 491 \\
\hline & $15^{\circ} \mathrm{C}$ altı sıcaklık & 707 & 680 & 672 & 613 & 690 & 694 & 744 & 699 & 744 & 744 & 636 \\
\hline & $15^{\circ} \mathrm{C}$ ve üstü sıcaklık & 37 & 64 & 72 & 131 & 54 & 50 & 0 & 45 & 0 & 0 & 108 \\
\hline
\end{tabular}

Şekil 4. Aylık ve yıllık üç farklı denge sıcaklı̆̆ için görülme saatleri 
Şekil 4'te verilen yıllık farklı denge sıcaklıkları için gerçekleştirme saat sayısı değerleri bulunup, Tablo 2' de verilmiş ve Şekil 5'te gösterilmiştir. Buna göre, yıllık $5{ }^{\circ} \mathrm{C}$ altı sıcaklıkların maksimum saati 1849 'dur, ortalaması ise $1454^{\prime}$ tür. $10^{\circ} \mathrm{C}$ altı sıcaklıkların için yıllık bu değer maksimum 3688 saattir, ortalaması ise $2989^{\prime}$ dur. $15^{\circ} \mathrm{C}$ altı sıcaklıkların saati ise maksimum $4614^{\prime}$ 'tür, ortalaması da 4176 'dır. Y1llık $15^{\circ} \mathrm{C}$ üstü sıcaklıkların saat değerleri maksimum 1142'dir, ortalama ise 920 olarak elde edilmiştir.

Tablo 2. Yıllık denge sıcaklı̆̆ için gerçekleştirme saat sayıları.

\begin{tabular}{lllll}
\hline YILLAR & $\begin{array}{l}\mathbf{1 5}^{\mathbf{}} \mathbf{C} \text { üstü Yıllık } \\
\text { Gerçekleştirme } \\
\text { saat sayısı }\end{array}$ & $\begin{array}{l}\mathbf{5}^{\mathbf{}} \mathbf{C} \text { altı Yıllık } \\
\text { Gerçekleştirme } \\
\text { saat sayısı }\end{array}$ & $\begin{array}{l}\mathbf{1 0}^{\mathbf{}} \mathbf{C} \text { altı Yıllık } \\
\text { Gerçekleştirme } \\
\text { saat sayısı }\end{array}$ & $\begin{array}{l}\mathbf{1 5}^{\circ} \mathbf{C} \text { altı Yıllık } \\
\text { Gerçekleştirme } \\
\text { saat sayısı }\end{array}$ \\
\hline 2007 & 838 & 1485 & 3204 & 4250 \\
\hline 2008 & 1100 & 1482 & 2767 & 4012 \\
\hline 2009 & 852 & 1297 & 2861 & 4136 \\
\hline 2010 & 1142 & 1142 & 2490 & 3946 \\
\hline 2011 & 474 & 1812 & 3688 & 4614 \\
\hline 2012 & 1035 & 1849 & 2982 & 4077 \\
\hline 2013 & 858 & 1398 & 2994 & 4230 \\
\hline 2014 & 1009 & 937 & 2673 & 4079 \\
\hline 2015 & 928 & 1678 & 3146 & 4160 \\
\hline 2016 & 953 & 1727 & 2957 & 4159 \\
\hline 2017 & 824 & 1386 & 3109 & 4264 \\
\hline
\end{tabular}

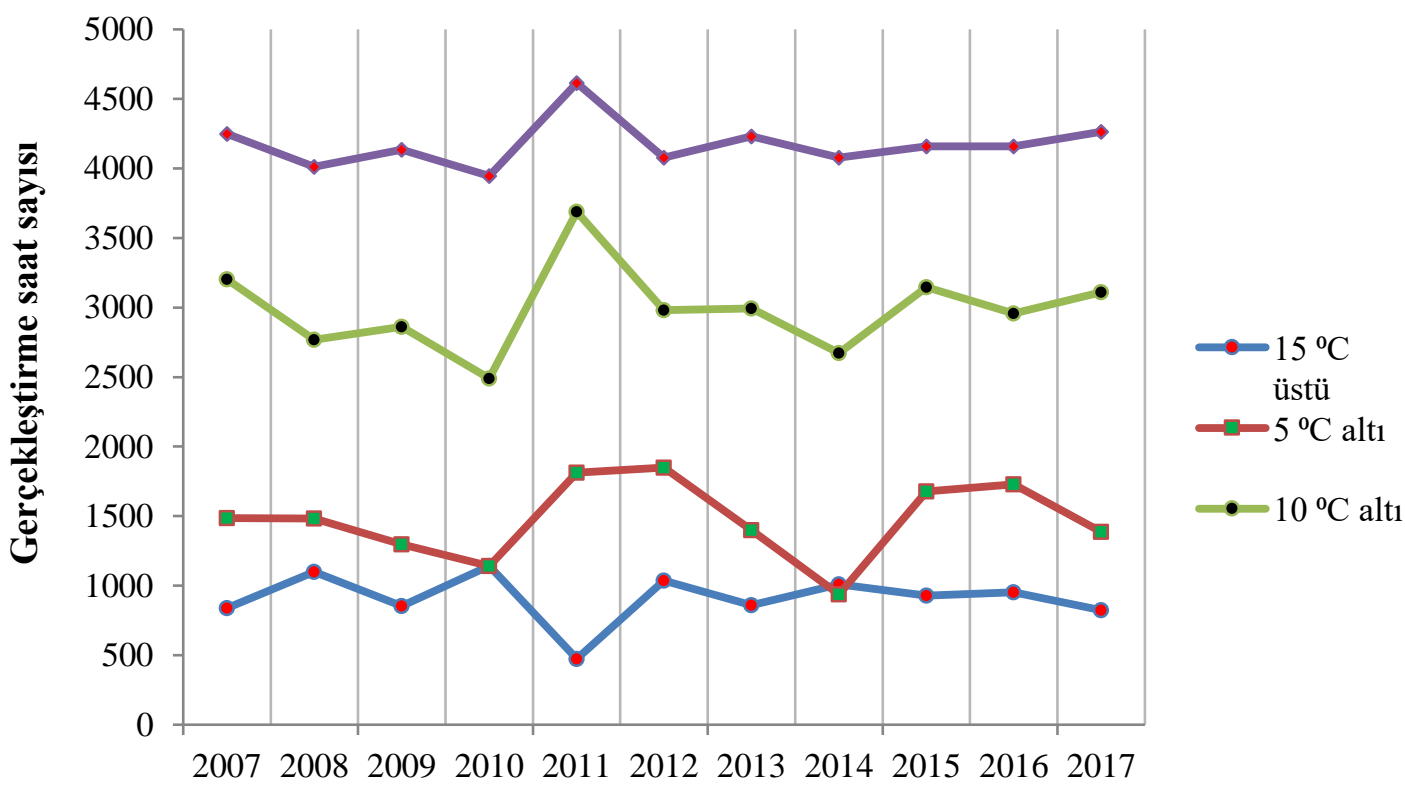

Yillar

Şekil 5. Ylllk farklı denge sıcaklıkları saat değerleri

\section{B. SOĞUTMA DERECE ZAMAN HESAPLAMALARI IÇíN ANALIZ VE DEĞERLENDIRME}

Düzce ili için meteorolojik veri setinden elde edilen 11 yıllık sıcaklık verilerine göre ortalama sıcaklığı $22{ }^{\circ} \mathrm{C}$ 'nin üstünde kalan gün sayıları hesaplanarak Şekil 6 'da gösterildiği gibi verilmiştir. $22{ }^{\circ} \mathrm{C}$ 'nin 
üstünde kalan yani soğutma ihtiyacı olan gün sayısı en az 46 gün ile 2011 yılında en fazla 84 gün ile 2010 yılında gerçekleşmiş̧ir. Ortalama soğutma ihtiyacı bulunan gün sayısı ise 71 gündür.

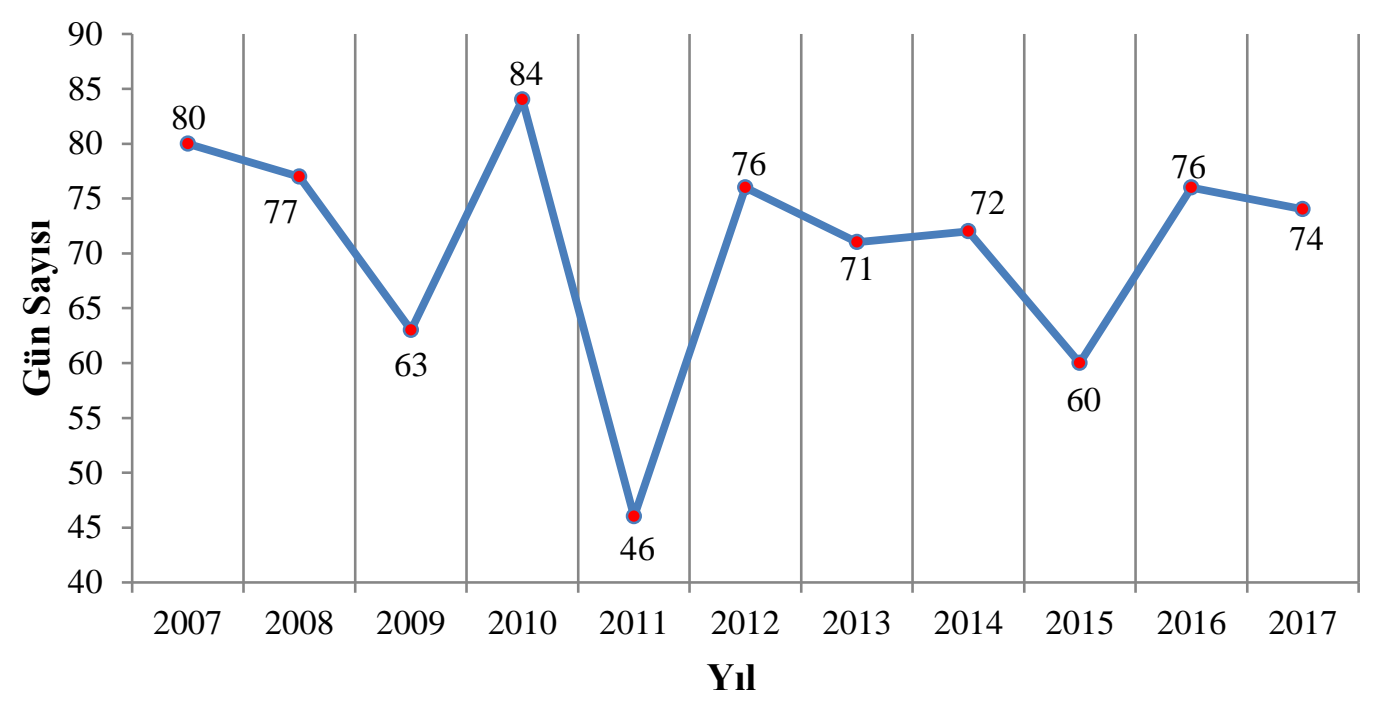

Şekil 6. Yıllara göre ortalama sıcaklı̆̆ı $22^{\circ}$ C'nin üstünde kalan günleri gösteren grafik

Yine 11 yılın meteorolojik veri kullanılarak yapılan hesaplamalarda $22^{\circ} \mathrm{C}$ denge sıcaklığ 1 için soğutma derece gün değerleri hesaplanarak Şekil 7'de gösterildiği gibi verilmiştir. En fazla soğutma derece gün değeri 253 ile 2010 yılında en az soğutma derece gün değeri ise 83 ile 2011 yılında gerçekleşmiştir. Ayrıca ortalama yıllık 154 soğutma derece gün değeri elde edilmiştir.

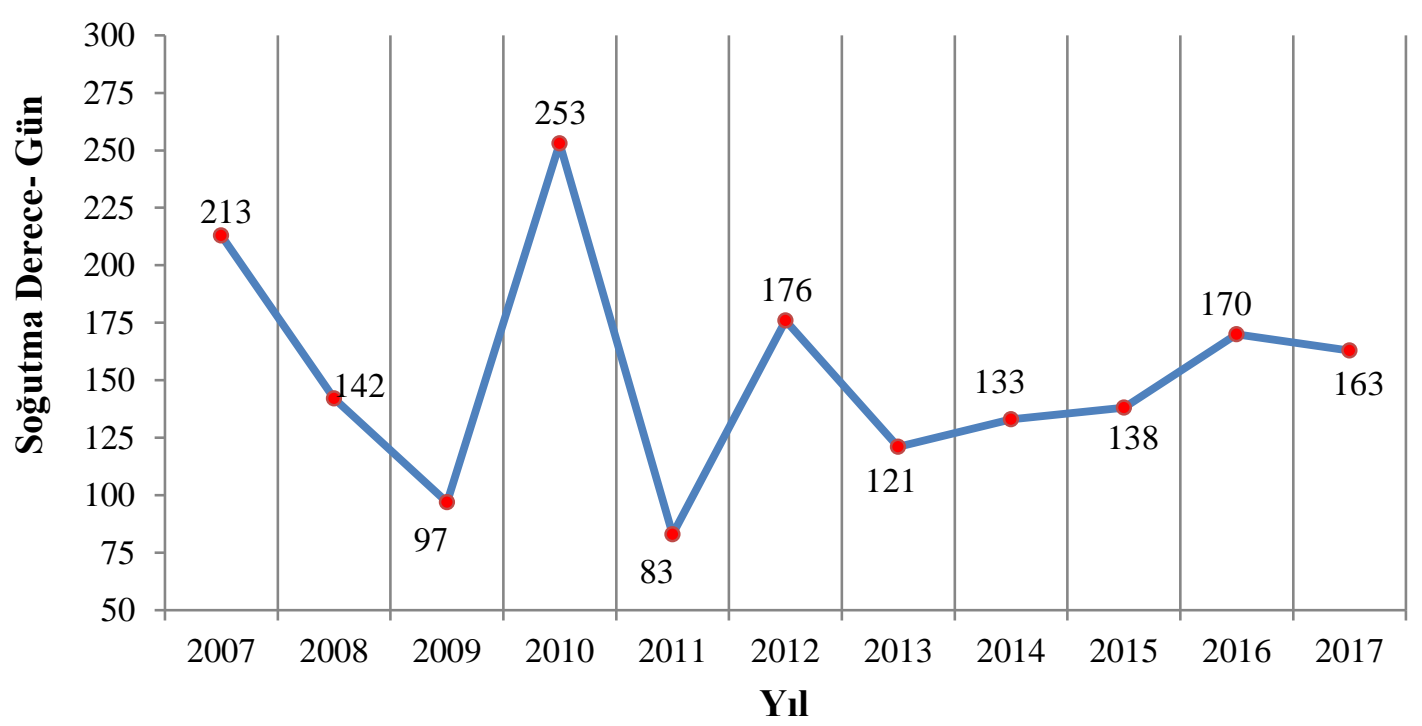

Şekil 7. $22^{\circ} \mathrm{C}$ için soğutma derece gün değerleri

Derece gün hesabından sonra mukayese için derece saat hesabı yapılmıştır. Yıllık farklı denge sıcaklıkları saat değerleri Tablo 4'te verilmiştir. Meteorolojik veri setinin 11 yıllık aylara ait verilerine baktığımızda; aylık $22{ }^{\circ} \mathrm{C}$ üstü sıcaklıklar için 451 ile 146 saat değerleri arasında ve ortalaması 311 saat, $27^{\circ} \mathrm{C}$ üstü sıcaklıklarda ise 191 ile 39 saat aralığında ortalama 118 saat, $32^{\circ} \mathrm{C}$ üstü sıcaklıklarda 29 ile 3 saat aralığında değişmiş ve ortalama 17 saat değeri elde edilmiştir. 


\begin{tabular}{|c|c|c|c|c|c|c|c|c|c|c|c|c|}
\hline \multirow[b]{2}{*}{ AYLAR } & \multirow{2}{*}{$\begin{array}{c}\text { REFERANS } \\
\text { SICAKLIKLAR }\end{array}$} & \multicolumn{11}{|c|}{ YILLAR } \\
\hline & & 2007 & 2008 & 2009 & 2010 & 2011 & 2012 & 2013 & 2014 & 2015 & 2016 & 2017 \\
\hline \multirow{3}{*}{ MAYIS } & $22{ }^{\circ} \mathrm{C}$ üstü slcakllk & 191 & 136 & 138 & 201 & 102 & 126 & 243 & 137 & 149 & 102 & 80 \\
\hline & $27^{\circ} \mathrm{C}$ üstü slcakllik & 56 & 36 & 34 & 63 & 15 & 19 & 81 & 30 & 44 & 33 & 11 \\
\hline & $32{ }^{\circ} \mathrm{C}$ üstü slcakllk & 5 & 4 & 3 & 0 & 0 & 0 & 14 & 0 & 0 & 0 & 2 \\
\hline \multirow{3}{*}{ HAZIRAN } & $22{ }^{\circ} \mathrm{C}$ üstü slcakllk & 346 & 319 & 336 & 290 & 229 & 338 & 338 & 238 & 181 & 350 & 294 \\
\hline & $27^{\circ} \mathrm{C}$ üstü slcakllik & 155 & 129 & 143 & 91 & 46 & 172 & 111 & 76 & 12 & 151 & 108 \\
\hline & $32{ }^{\circ} \mathrm{C}$ üstü slcakllk & 37 & 10 & 21 & 9 & 6 & 20 & 10 & 5 & 0 & 25 & 12 \\
\hline \multirow{3}{*}{ TEMMUZ } & $22{ }^{\circ} \mathrm{C}$ üstü slcakllk & 460 & 397 & 424 & 525 & 460 & 506 & 383 & 420 & 394 & 424 & 446 \\
\hline & $27^{\circ} \mathrm{C}$ üstü slcakllk & 213 & 195 & 158 & 220 & 228 & 249 & 142 & 166 & 137 & 160 & 162 \\
\hline & $32{ }^{\circ} \mathrm{C}$ üstü slcakllk & 49 & 22 & 14 & 23 & 30 & 48 & 6 & 14 & 32 & 14 & 37 \\
\hline \multirow{3}{*}{ AĞUSTOS } & $22{ }^{\circ} \mathrm{C}$ üstü slcakllik & 469 & 477 & 355 & 610 & 339 & 391 & 426 & 438 & 493 & 501 & 462 \\
\hline & $27^{\circ} \mathrm{C}$ üstü slcakllik & 211 & 235 & 108 & 321 & 112 & 184 & 197 & 170 & 203 & 186 & 164 \\
\hline & $32{ }^{\circ} \mathrm{C}$ üstü slcakllik & 33 & 46 & 5 & 103 & 0 & 40 & 16 & 19 & 14 & 30 & 11 \\
\hline \multirow{3}{*}{ EYLÜL } & $22{ }^{\circ} \mathrm{C}$ üstü slcakllk & 252 & 188 & 164 & 224 & 215 & 255 & 172 & 188 & 315 & 204 & 244 \\
\hline & $27^{\circ} \mathrm{C}$ üstü slcakllik & 76 & 73 & 24 & 58 & 71 & 85 & 36 & 38 & 99 & 56 & 102 \\
\hline & $32{ }^{\circ} \mathrm{C}$ üstü slcakllik & 10 & 10 & 3 & 0 & 1 & 7 & 3 & 0 & 34 & 7 & 24 \\
\hline
\end{tabular}

Şekil 8. Aylık ve ylllk üç farklı denge sıcakllğı için görülme saatleri

Şekil 8'de verilen yıllık farklı denge sıcaklıkları için toplam gerçekleştirme saat sayısı değerleri bulunup Tablo 3'de verilmiş ve Şekil 9'da gösterilmiştir. Yıllık farklı denge sıcaklıkları için toplam gerçekleşme saatleri, meteorolojik veri setinin 11 yıllık aylara ait verilere bakıldığında Şekil 7'de verildiği gibi, aylık $22^{\circ} \mathrm{C}$ üstü sıcaklıklar için 1850 saat maksimum değer ve ortalaması da 1554 saat. $27^{\circ} \mathrm{C}$ üstü sıcaklıkların saati maksimum $753^{\prime}$ tür, ortalamas 118 saat. $32^{\circ} \mathrm{C}$ üstü sıcaklıklar da ise 135 saat maksimum değer ile ortalama 81 saat değeri elde edilmiştir.

Tablo 3. Ylllık üç farklı denge sıcakllğı için toplam gerçekleşme saat sayıları

\begin{tabular}{cccc}
\hline YILLAR & $\mathbf{3 2}^{\mathbf{C}} \mathbf{C}$ üstü & $\mathbf{2 7}^{\mathbf{C}} \mathbf{~ u ̈ s t u ̈ ~}$ & $\mathbf{2 2}^{\mathbf{}} \mathbf{C}$ üstü \\
\hline 2007 & 134 & 711 & 1718 \\
\hline 2008 & 92 & 668 & 1517 \\
\hline 2009 & 46 & 467 & 1417 \\
\hline 2010 & 135 & 753 & 1850 \\
\hline 2011 & 37 & 472 & 1345 \\
\hline 2012 & 115 & 709 & 1616 \\
\hline 2013 & 49 & 567 & 1562 \\
\hline 2014 & 38 & 480 & 1421 \\
\hline 2015 & 80 & 495 & 1532 \\
\hline 2016 & 76 & 586 & 1581 \\
\hline 2017 & 86 & 547 & 1526 \\
\hline
\end{tabular}




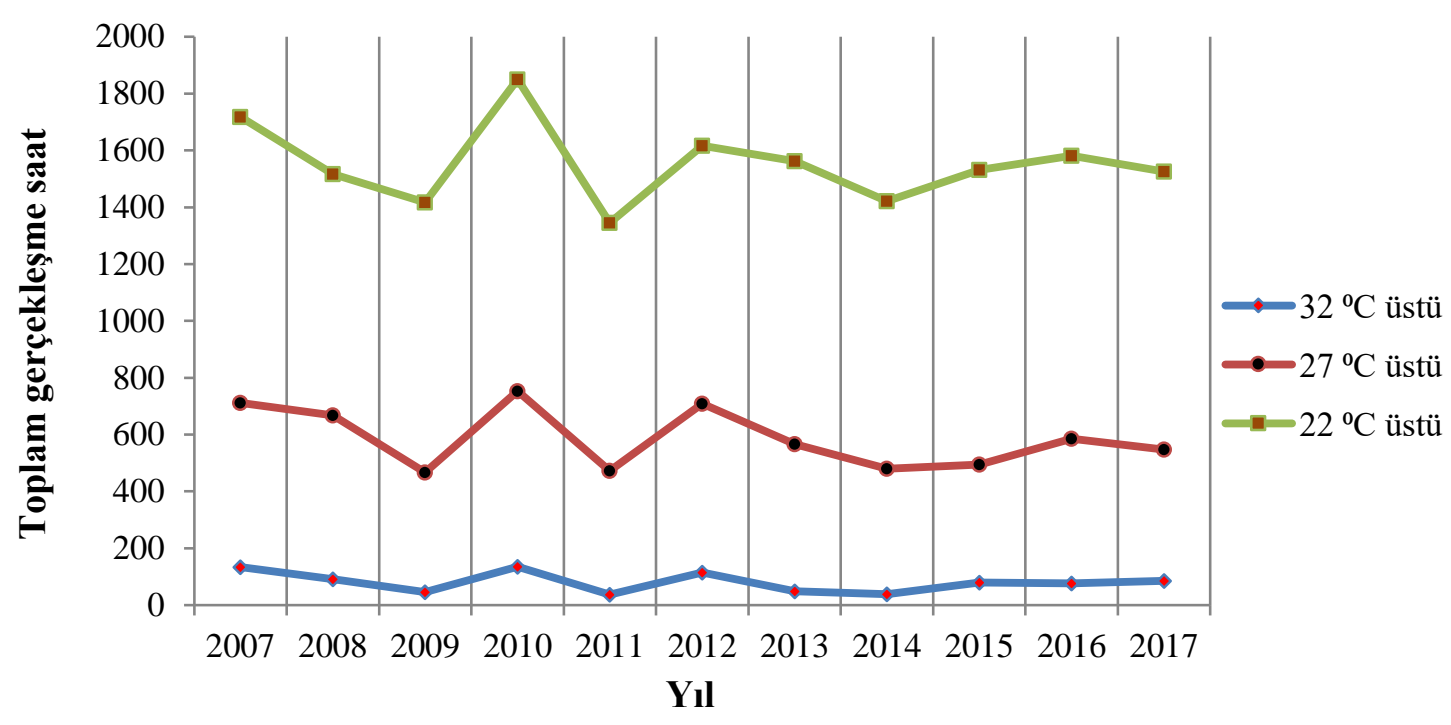

Şekil 9. Yıllık farklı denge sıcaklıkları için toplam gerçekleşme saatleri.

\section{IZOLASYON MALZEMELERİ İÇİ KALINLIK, ISI TASARRUFU VE MALIYETIN KENDINII AMORTİ ETME SÜRECI HESABI ANALIZİ}

Düzce ilinde farklı duvar yapıları ve sekiz farklı izolasyon malzemelerinin kullanıldığı, duvar malzemesi, iç ve dış sıva ile ilgili veriler Tablo 4'te verilmiştir.

Tablo 4. Düzce ili sekiz farklı izolasyonlu bina tipi için yapı malzemesi bilgileri

\begin{tabular}{|c|c|c|c|c|c|c|c|}
\hline Bina & İzolas & yon Malzen & & Duvar Mz & emesi & SI & \\
\hline Tip & $\underset{\left(\mathrm{kg} / \mathrm{m}^{3}\right)}{\operatorname{Tip}}$ & $\begin{array}{l}\text { İzolasyo } \\
\text { n } \\
\text { Kalınlığı } \\
\quad(m)\end{array}$ & $\begin{array}{c}\text { İletim } \\
\text { kat sayısı } \\
(\boldsymbol{k}) \\
(\mathrm{W} / \mathrm{mK})\end{array}$ & $\begin{array}{c}\text { Duvar } \\
\text { Tipi }\end{array}$ & $\begin{array}{c}\text { Kalınlı } \\
\mathbf{k} \\
(\boldsymbol{m})\end{array}$ & $\begin{array}{l}\text { İç Sıva } \\
\text { Kalınlığı } \\
(m)\end{array}$ & $\begin{array}{c}\text { Dış Sıva } \\
\text { Kalınlığ } \\
(m)\end{array}$ \\
\hline 1 & Taş Yünü 50 & 0,04 & 0,04 & $\begin{array}{l}\text { Yatay } \\
\text { Delikli } \\
\text { Tuğla }\end{array}$ & 0,19 & 0,02 & 0,008 \\
\hline 2 & EPS 16 & 0,04 & 0,039 & $\begin{array}{c}\text { Yatay } \\
\text { Delikli } \\
\text { Tuğla } \\
\end{array}$ & 0,19 & 0,02 & 0,008 \\
\hline 3 & EPS 20 & 0,04 & 0,035 & $\begin{array}{c}\text { Yatay } \\
\text { Delikli } \\
\text { Tuğla } \\
\end{array}$ & 0,19 & 0,02 & 0,008 \\
\hline 4 & XPS 24 & 0,04 & 0,032 & $\begin{array}{l}\text { Yatay } \\
\text { Delikli } \\
\text { Tuğla }\end{array}$ & 0,19 & 0,02 & 0,008 \\
\hline 5 & Taş Yünü 50 & $\begin{array}{c}\text { İzolasyon } \\
\text { yok }\end{array}$ & & Gaz Beton & 0.2 & 0,02 & 0,008 \\
\hline 6 & EPS 16 & $\begin{array}{c}\text { İzolasyon } \\
\text { yok }\end{array}$ & & Gaz Beton & 0.2 & 0,02 & 0,008 \\
\hline 7 & EPS 20 & $\begin{array}{c}\text { İzolasyon } \\
\text { yok }\end{array}$ & & Gaz Beton & 0.2 & 0,02 & 0,008 \\
\hline 8 & XPS 24 & $\begin{array}{c}\text { İzolasyon } \\
\text { yok }\end{array}$ & & Gaz Beton & 0.2 & 0,02 & 0,008 \\
\hline
\end{tabular}


Yapılan çalışmada tuğla ve gaz beton olmak üzere Tablo 4'te verildiği gibi iki tip duvar ve farklı izolasyon malzemesi kullanılmıştır. Bu bina tipleri seçilirken, daha önce Düzce ilinde ve bölgesinde yapılan bina izolasyon tipleri temel alınmıştır. Binalar yapılırken izolasyon kalınlığı hesabı yapılmadığı için standart olarak $4 \mathrm{~cm}$ izolasyon malzemesi kullanılmış. Binaların birçoğunda Neopor, (EPS), taş yünü ya da XPS izolasyon malzemelerinin de kullanıldığı görülmektedir. Çalışmada bu bina tipleri için yıllık 1sıtma maliyeti, izolasyon maliyeti, geri ödeme süresi ve enerji tasarruf yüzdesi dikkate alınarak izolasyon kalınlığ işlenmesi ve sekiz farklı izolasyona sahip bina için verilerin yazılması ile yapılan hesaplamalar Tablo 5 'te gösterilmektedir.

Tablo 5. Sekiz farklı izolasyona sahip bina tipi için yapılan hesaplamaların sonuçları.

\begin{tabular}{|c|c|c|c|c|c|c|c|c|}
\hline $\begin{array}{l}\text { Bina } \\
\text { Tipi }\end{array}$ & $\begin{array}{c}\text { İzolasyon } \\
\text { Malzemesi } \\
\left(\mathrm{kg} / \mathrm{m}^{3}\right)\end{array}$ & $\begin{array}{c}\text { Ortalama } \\
\text { HDD } \\
\left({ }^{\circ} \mathrm{C} / \text { Gün } n\right)\end{array}$ & $\begin{array}{c}\text { Yillhk } \\
\text { Isttma } \\
\text { Maliyet } \\
\text { i } \\
\left(T L / m^{2}\right)\end{array}$ & $\begin{array}{c}\text { Tasarru } \\
\text { f } \\
\text { Miktarı } \\
(\%)\end{array}$ & $\begin{array}{c}\text { Geri } \\
\text { Ödeme } \\
\text { Süresi } \\
(y l l)\end{array}$ & $\begin{array}{c}\text { İzolasyon } \\
\text { Kalınlığı } \\
(m)\end{array}$ & $\begin{array}{c}\text { İzolasyon } \\
\text { Maliyeti } \\
\left(T L / m^{2}\right)\end{array}$ & $\begin{array}{c}\text { Düşük } \\
\text { izolasyon } \\
\text { kalınlığın } \\
\text { dan } \\
\text { ötürü } \\
\text { enerji } \\
\text { kaybı } \\
(\%)\end{array}$ \\
\hline $\begin{array}{c}1 \\
\text { no'lu }\end{array}$ & $\begin{array}{l}\text { Taş Yünü } \\
50\end{array}$ & 1938 & 3,63 & 68,73 & 4,34 & 0,0429 & 34,637 & 1,3 \\
\hline $\begin{array}{c}2 \\
\text { no'lu }\end{array}$ & EPS 16 & 1938 & 3,326 & 71,35 & 4,045 & 0,0483 & 33,52 & 3,45 \\
\hline $\begin{array}{c}3 \\
\text { no'lu }\end{array}$ & EPS 20 & 1938 & 3,28 & 71,74 & 3,99 & 0,0443 & 33,31 & 1,84 \\
\hline $\begin{array}{c}4 \\
\text { no'lu } \\
\end{array}$ & XPS 24 & 1938 & 3,354 & 71,11 & 4,067 & 0,0392 & 33,587 & yok \\
\hline $\begin{array}{c}5 \\
\text { no'lu } \\
\end{array}$ & Taş Yünü & 1938 & 3,635 & 43,01 & 5,444 & 0,0185 & 14,937 & 43,01 \\
\hline $\begin{array}{c}6 \\
\text { no'lu } \\
\end{array}$ & EPS 16 & 1938 & 3,326 & 47,85 & 5,593 & 0,0247 & 17,072 & 47,85 \\
\hline $\begin{array}{c}7 \\
\text { no'lu }\end{array}$ & EPS 20 & 1938 & 3,28 & 48,54 & 5,586 & 0,023 & 17,296 & 48,54 \\
\hline $\begin{array}{c}8 \\
\text { no'lu }\end{array}$ & XPS 24 & 1938 & 3,351 & 47,45 & 5,59 & 0,0197 & 16,922 & 47,45 \\
\hline
\end{tabular}

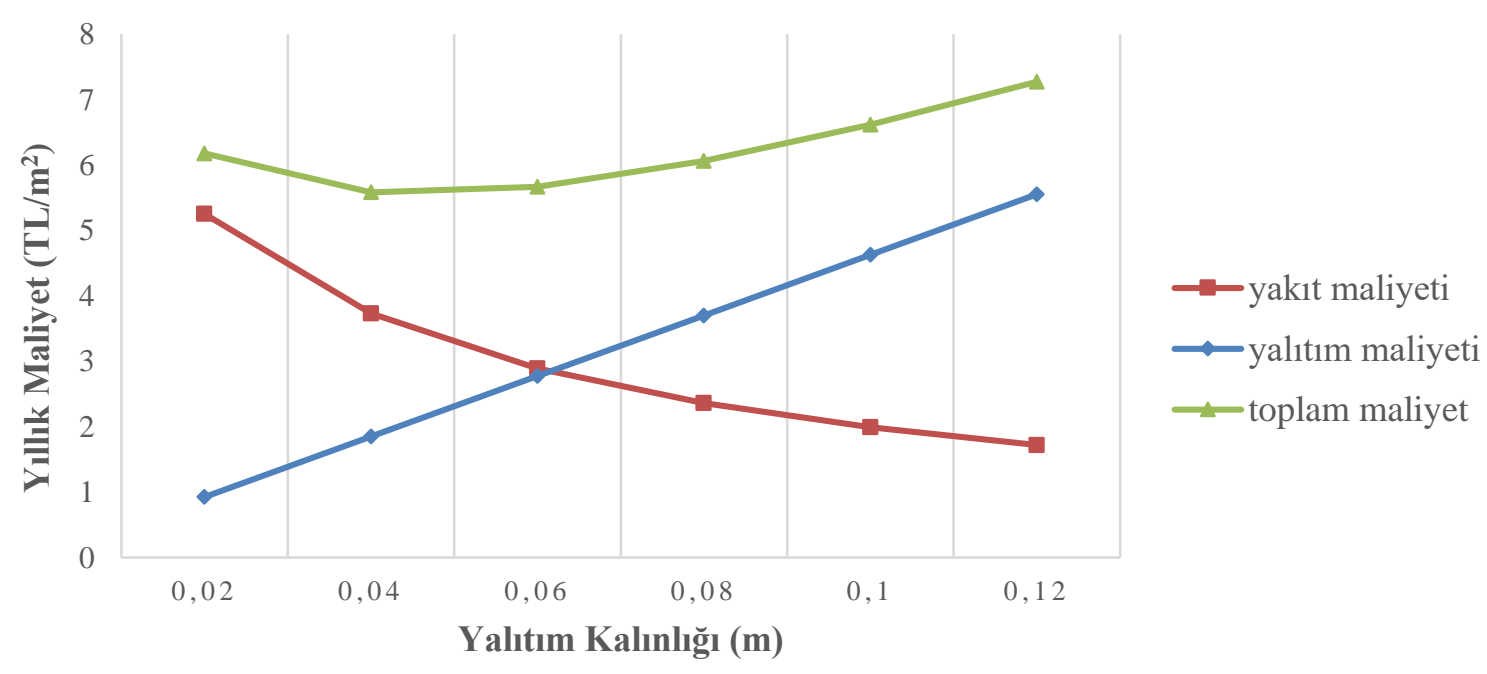

Şekil 10. Tuğla Duvar $16 \mathrm{~kg} / \mathrm{m}^{3}$ EPS için izolasyon kalınlı̆̆ ile maliyet arasındaki ilişki 


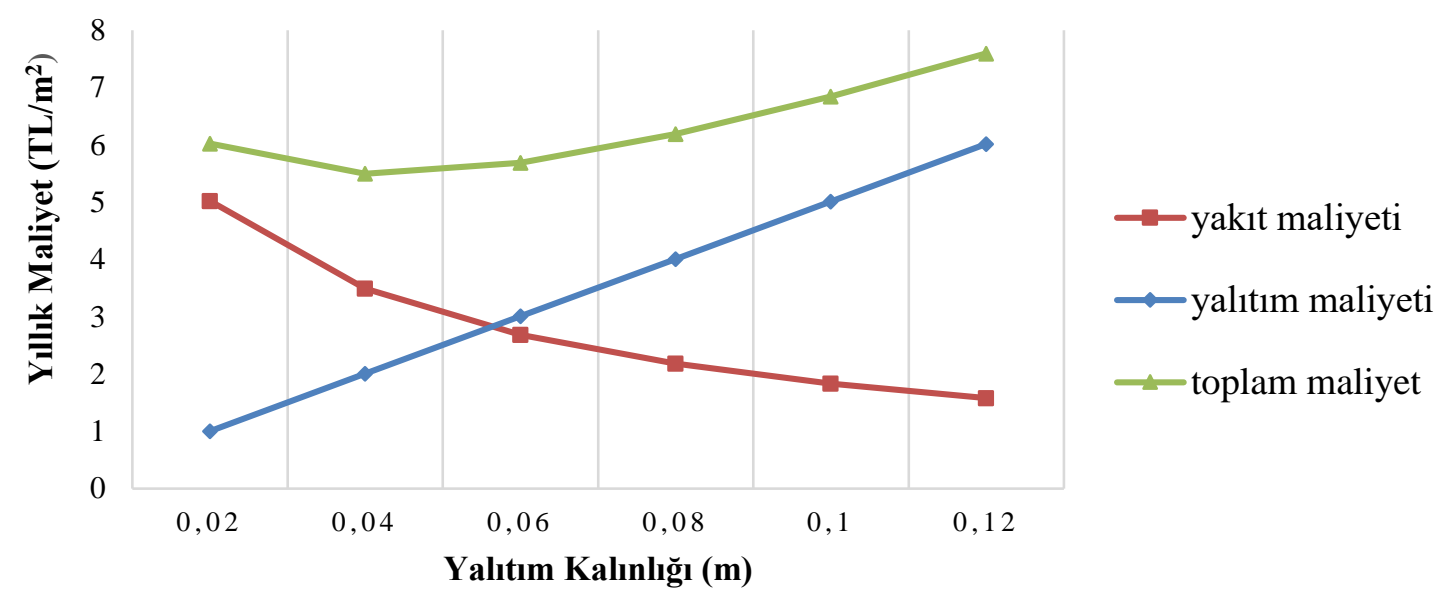

Şekil 11. Tuğla Duvar $20 \mathrm{~kg} / \mathrm{m}^{3}$ EPS için izolasyon kalınlı̆̆ı ile maliyet arasındaki ilişki

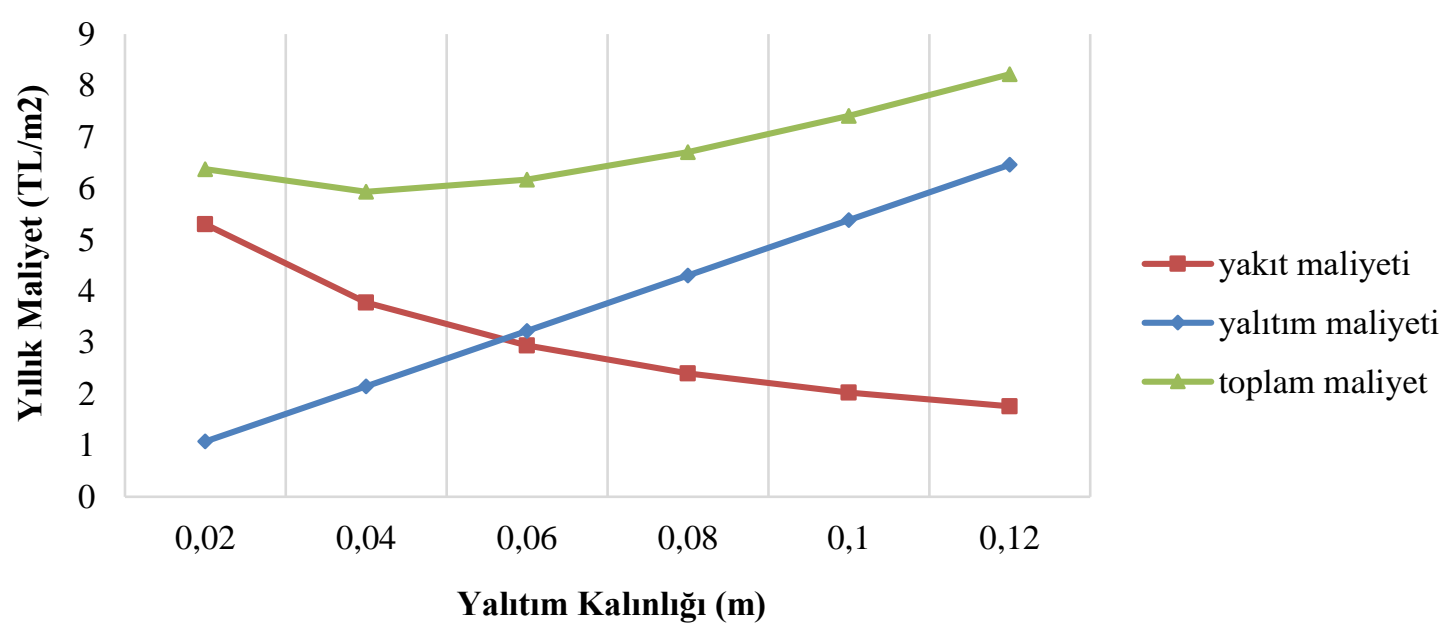

Şekil 12. Tuğla duvar $50 \mathrm{~kg} / \mathrm{m}^{3}$ taş yünü için izolasyon kalınlığı ile maliyet arasındaki ilişki

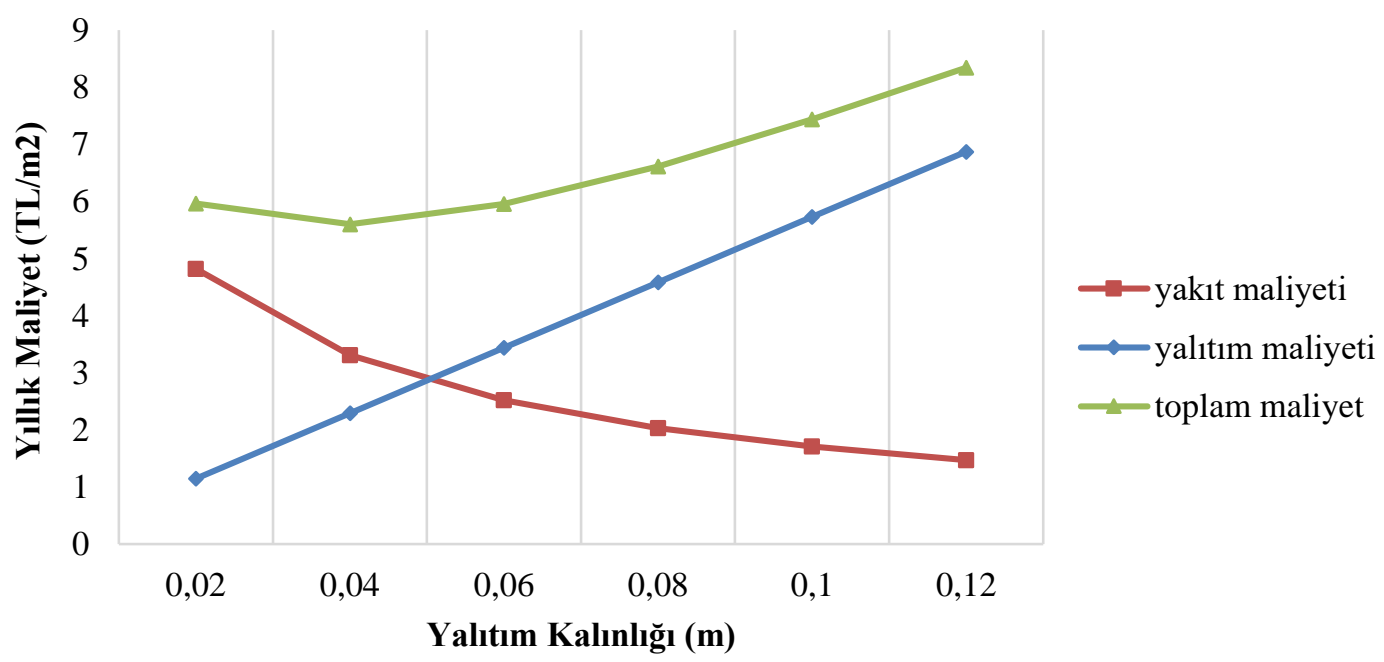

Şekil 13. Tuğla Duvar $24 \mathrm{~kg} / \mathrm{m}^{3}$ XPS için izolasyon kalınlı̆̆ı ile maliyet arasındaki ilişski 


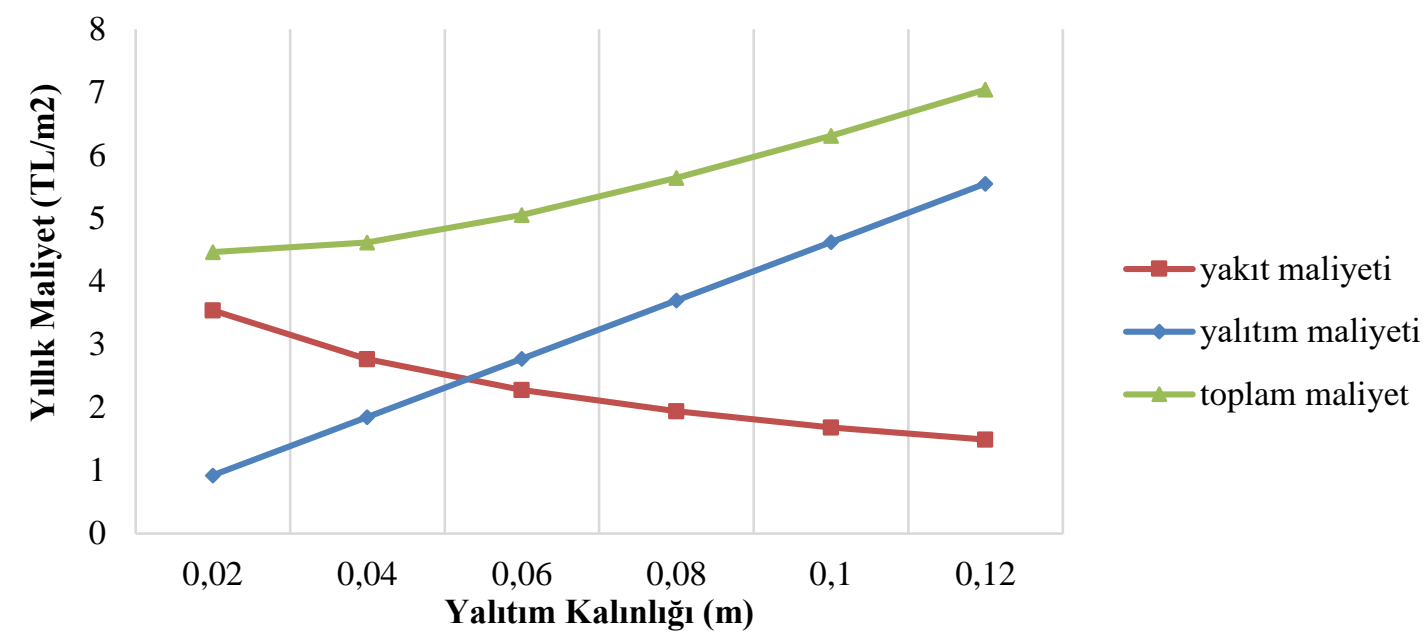

Şekil 14. Gaz Beton Duvar $16 \mathrm{~kg} / \mathrm{m}^{3}$ EPS için izolasyon kalınlı̆̆ı ile maliyet arasındaki ilişski

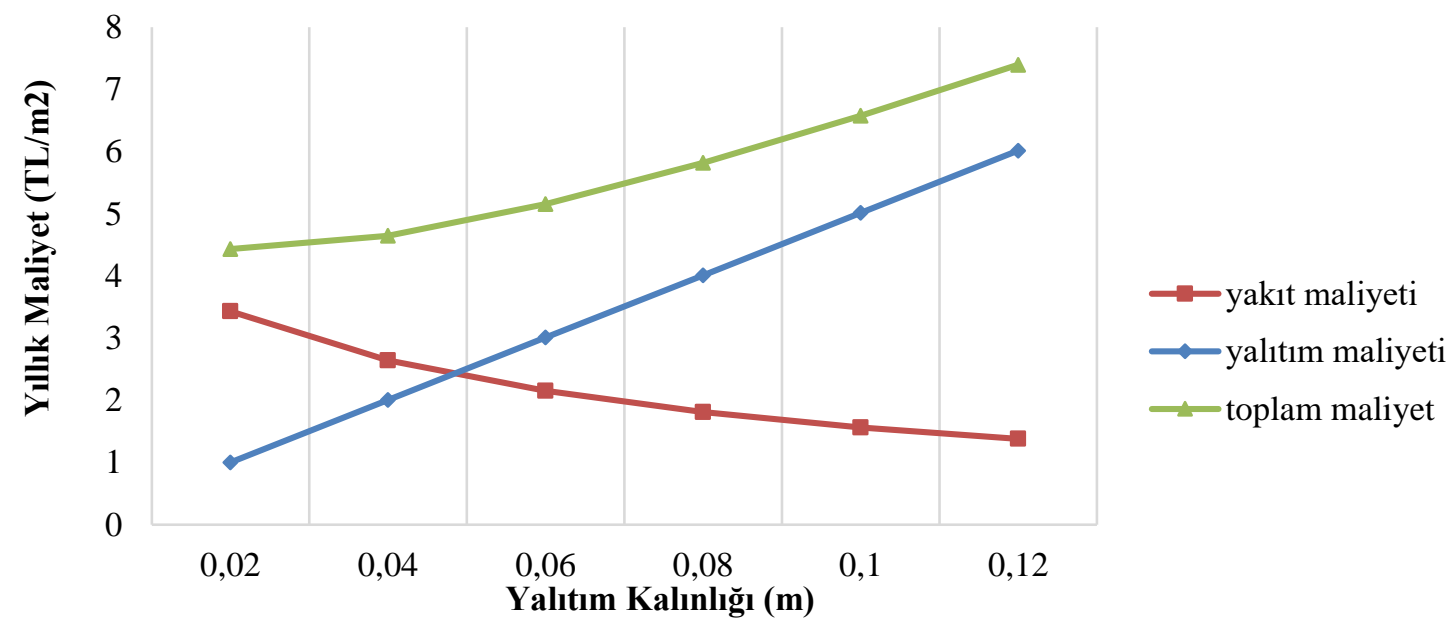

Şekil 15. Gaz Beton Duvar $20 \mathrm{~kg} / \mathrm{m}^{3}$ EPS için izolasyon kalınlı̆̆ ile maliyet arasındaki iliş̧ki

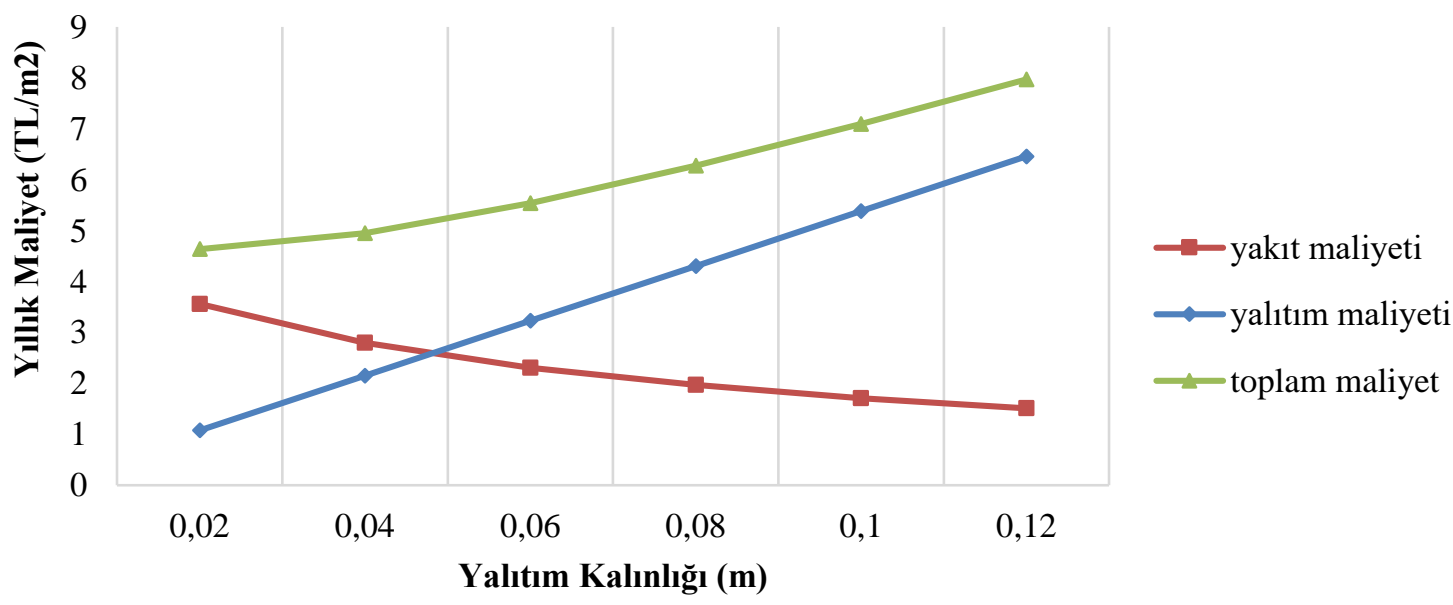

Şekil 16. Gaz Beton Duvar $50 \mathrm{~kg} / \mathrm{m}^{3}$ taş yünü için izolasyon kalınlığı ile maliyet arasındaki ilişski 


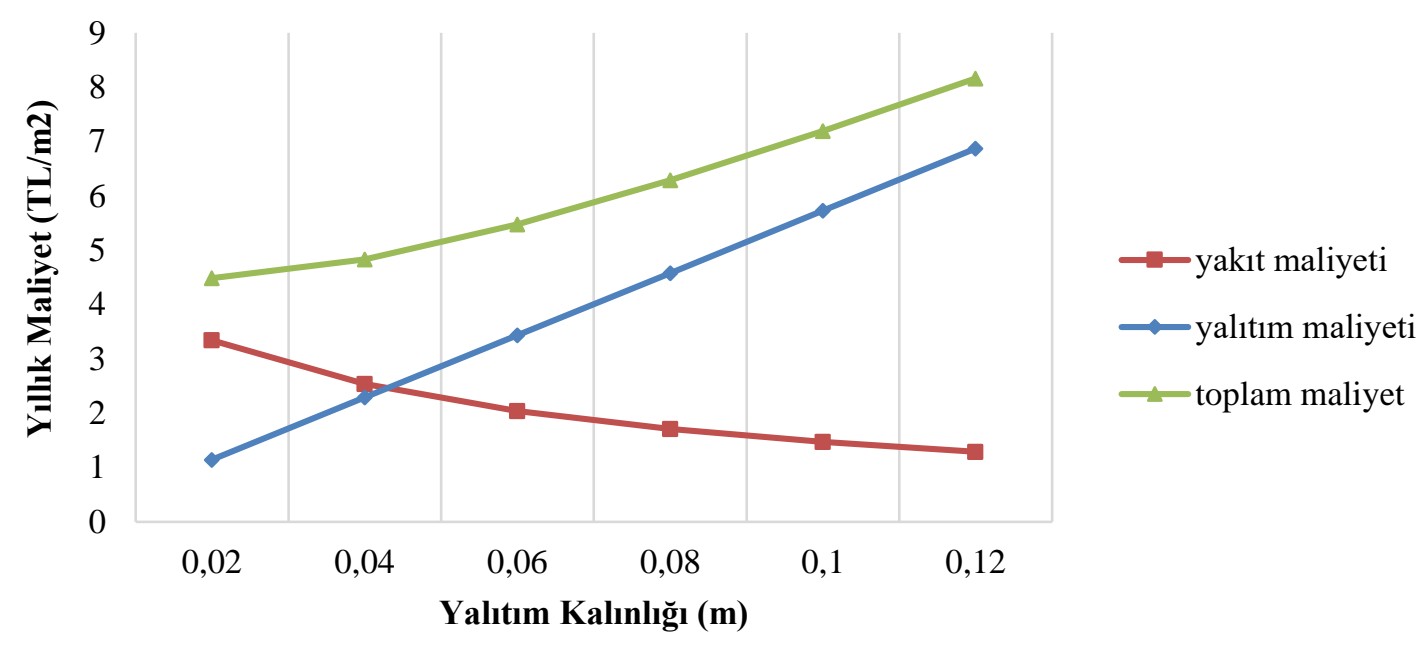

Şekil 17. Gaz Beton Duvar $24 \mathrm{~kg} / \mathrm{m}^{3}$ XPS için izolasyon kalınlı̆̆ ile maliyet arasındaki ilişki

Grafikler incelendiğinde, izolasyon kalınlığı ile birlikte izolasyon maliyeti yükselmekte ancak yakıt maliyeti düşmektedir. Toplam maliyet önce düşmekte daha sonra yükselmektedir. Bu da izolasyon kalınlığı artışı ile yakıt maliyetindeki düşüşün sürekli aynı oranda devam etmediğini göstermektedir. Toplam maliyetin en az olduğu nokta, izolasyon kalınlığının bulunduğu noktadır. Bu noktadan itibaren, izolasyona sarf edilen para yakıttan tasarruf edilen maliyet miktarını karşılamadığı için, izolasyon malzemesinin kalınlığının bu noktadan itibaren artması zarar olacaktır. Dıştan izolasyonlu duvar tiplerinde, yapı malzemesi olarak tuğla kullanımıyla gerçekleşen yıllık kazanç, yapı malzemesi olarak gaz beton kullanılan duvar tipine göre daha fazla çıkmıştır. Bu durumun oluşmasındaki neden, gaz beton malzemesinin 1sıl iletkenlik değerinin tuğlaya göre daha düşük olmasıdır. Gaz beton duvardan gerçekleşen 1S1 kaybı, tuğla duvara göre düşük olduğundan izolasyona olan ihtiyaç azalmaktadır. Tuğla duvarda ise, daha yüksek 1sı kaybı olacağından dolayı izolasyon kalınlığı artacak, bununla beraber toplam maliyet ve tasarruf oranı da artacaktır. Sekiz bina tipinden elde edilen sonuçlar ve yapılan değerlendirmeye göre, tuğla duvar ve $4 \mathrm{~cm}$ izolasyon malzemesi kullanılan bina tiplerinde düşük izolasyon kalınlığından ötürü enerji kaybı yüzde 1,3 ile yüzde 3,45 oranlarında olduğu için, izolasyon kalınlıklarının yüksek değerlerine yükseltilmesi tavsiye edilmemektedir. Ancak, gaz beton duvar ve izolasyonsuz bina tiplerinde bina için gerekli hesaplamalar yapılarak elde edilen izolasyon değerleri ile binan izole edildiğinde, yüzde 43,01 ile yüzde 48,54 oranlarında enerji tasarrufu edileceğinden, ayrıca duvarlar ile birlikte binanın dış yüzeye bakan kolon-kiriş bölümleri de izole edilmiş olacağından enerji tasarrufu daha da artacaktır. Gaz beton duvar ile inşa edilmiş olan 5, 6, 7 ve 8 no'lu bina tiplerinde izolasyon yapılması tavsiye edilmektedir.

\section{IV.SONUC}

Düzce ilinde yapılan binaları incelediğimizde, tuğla ve gaz beton olmak üzere iki tip duvara rastlanmaktadır. 8 bina tipinden elde edilen sonuçlar ve yapılan değerlendirmeye göre, tuğla duvar ve $4 \mathrm{~cm}$ izolasyon malzemesi kullanılan bina tiplerinde düşük izolasyon kalınlığından ötürü enerji kaybı yüzde 1,3 ve yüzde 3,45 oranlarında olduğu için izolasyon kalınlıklarının optimum izolasyon değerlerine yükseltilmesi tavsiye edilmemektedir. Tuğla duvar üzerine farklı izolasyon malzemeleri kullanılmış ancak tüm izolasyon malzemelerinin kalınlığ $4 \mathrm{~cm}$ tercih edilmiştir. Binaların birçoğunda Neopor dediğimiz şişirilebilen ve genleştirilebilen polistiren (EPS) granüller şeklindeki siyah boncuk yapılı izolasyon malzemesi kullanılmakla birlikte, bazı bina tiplerinde taş yünü ya da XPS izolasyon malzemelerinin de kullanıldığı görülmektedir. Gaz beton duvar yapısına sahip binalarda ise, izolasyon malzemesi kullanılmamıştır. Bu çalışmada, Düzce şehri için 1sı yükü ve enerji tahminlerinde kullanılan hesaplamalarda, derece-zaman (derece-gün ve derece-saat) verileri hazırlanmıştır. Hesaplamalarda kullanılacak saatlik sıcaklık verileri (2007-2017 yılları arası), MGM Düzce Meteoroloji Müdürlüğü istasyonundan temin edilmiştir. Elde edilen veriler Excel ortamına aktarılmış, ortalama sıcaklık 
değerleri dikkate alınarak 1sıtma $15^{\circ} \mathrm{C}$, soğutma ise $22^{\circ} \mathrm{C}$ 'lik denge sıcaklıkları için derece zaman hesaplamaları yapılmıştır. Ayrıca, 11 yıl ve her yıl için 8760 saatlik sıcaklık verilerinden tablo ve grafikler elde edilmiş, elde edilen tablo grafik değerleri analiz edilerek yorumlanmıştır. Elde edilen bazı sonuçlar aşağıda özetlenmiştir:

Y1llık $22^{\circ} \mathrm{C}$ üstü sıcaklıkların saati maksimum 1850'dir; ortalama 1554'tür

Yıllık $15{ }^{\circ} \mathrm{C}$ denge sıcaklığında, 1sıtma ihtiyacının ortalama 192 gün olduğu belirlenmiştir.

Y1ll1k 1sitma derece-gün değeri, ortalama 1938'dir.

Y1llık $15^{\circ} \mathrm{C}$ denge sicaklığında, 1sıtma derece-saat değeri ortalama 4176 'dır.

Yıllık $22{ }^{\circ} \mathrm{C}$ denge sıcaklığında, soğutma ihtiyacının ortalama 71 gün olduğu belirlenmiştir.

Y1llık soğutma derece-gün değeri, ortalama 154'tür.

Yıllık $22{ }^{\circ} \mathrm{C}$ denge sicaklığında, soğutma derece-saat değeri ortalama 1554 'tür.

Yapılan hesaplamalara göre tuğla ve gaz beton duvarı kaplayan izolasyon malzemelerinin optimum kalınlık değerleri; $50 \mathrm{~kg} / \mathrm{m}^{3}$ taş yünü için tuğla duvar $0,0429 \mathrm{~m}$, gaz beton duvar $0,0185 \mathrm{~m}, 16 \mathrm{~kg} / \mathrm{m}^{3}$ EPS için tuğla duvar $0,0483 \mathrm{~m}$, gaz beton duvar $0,0247 \mathrm{~m}, 20 \mathrm{~kg} / \mathrm{m}^{3}$ EPS için tuğla duvar $0,0443 \mathrm{~m}$, gaz beton duvar $0,023 \mathrm{~m}, 24 \mathrm{~kg} / \mathrm{m}^{3}$ XPS için tuğla duvar $0,0392 \mathrm{~m}$ gaz beton duvar $0,0197 \mathrm{~m}$ olarak bulunmuştur.

Ayrıca farklı izolasyon malzemelerinin yıllık 1sitma maliyeti, izolasyondan elde edilen tasarruf miktarı, maliyetin kendini amorti etme süreci, birbirleriyle karşılaştırıldığında taş yünü; yatırım maliyeti, yıllık 1sıtma maliyeti ve maliyetin kendini amorti etme süreci bakımından en yüksek izolasyon malzemesidir. XPS izolasyon malzemesinin, 1sı iletim katsayısı yüksek olmasına rağmen yatırım maliyeti yüksek olduğu için, maliyetin kendini amorti etme süreci yine yüksek kalmaktadır. $16 \mathrm{~kg} / \mathrm{m}^{3}$ EPS, yıllık 1sıtma maliyeti en düşük olan malzeme olarak karşımıza çıkmaktadır, ancak 1sı iletim katsayısı XPS ve $20 \mathrm{~kg} / \mathrm{m}^{3}$ EPS'ye göre yüksek olduğu için, maliyetin kendini amorti etme sürecini arttırmaktadır. $20 \mathrm{~kg} / \mathrm{m}^{3}$ EPS'nin yıllık 1sıtma maliyeti $16 \mathrm{~kg} / \mathrm{m}^{3}$ EPS'ye göre biraz artmasına rağmen, tasarruf miktarının yüksek olması ve maliyetin kendini amorti etme süreci en düşük olan izolasyon malzemesi olduğu için, Düzce ilinde yapılacak binalara en uygun izolasyon malzemesinin, $20 \mathrm{~kg} / \mathrm{m}^{3}$ EPS olduğu tespit edilmiştir.

Gaz beton duvarın 1S1 iletim katsayısının tuğlaya göre daha düşük olması, optimum izolasyon kalınlıklarının da düşmesine sebep olmuştur. Ancak gaz beton duvar için $0.0185 \mathrm{~m}-0,0247 \mathrm{~m}$ arasında değișen optimum izolasyon kalınlıklarının bulunması gaz beton duvarın binanın izolasyonu için tek başına yeterli olmadığını göstermektedir. Gaz beton duvar ve izolasyonsız bina tiplerinde optimum izolasyon değerleri ile izolasyon yapıldığında \%43,01 ile \% 48,54 oranlarında enerji tasarrufu edileceğinden ayrıca duvarlar ile birlikte binanın dış yüzeye bakan kolon-kiriş bölümleri de izole edileceğinden ve enerji tasarrufu daha da artacağından dolayı gaz beton duvar kullanılsa bile izolasyon yapılması tavsiye edilmektedir.

\section{KAYNAKLAR}

[1] F. Ş. Sezer, "Türkiye'de Isı İzolasyonının Gelişimi ve Konutlarda Uygulanan Dış Duvar Isı İzolasyon Sistemleri," Uludağ Üniversitesi Mühendislik-Mimarlık Fakültesi Dergisi, c. 10, s. 2, ss. 79$85,2005$.

[2] N. Yüksel, "Günümüz Kamu Kurumlarında Yapısal Konfor Koşullarının Tespit Edilmesine Yönelik Bir Çalışma,” Uludă̆ Üniversitesi Mühendislik-Mimarlık Fakültesi Dergisi, c. 10, s. 2, ss. $21-31,2005$

[3] Ş. Puşat, N. Tunç, İ. Ekmekçi, Y. Yetişken, “Karabük İçin Derece Zaman Hesaplamaları,” 3rd International Symposium On Innnovative Technologies in Engineering and Science Universidad Politecnica de Valencia Spain, ss. 898-905, 3-5 June 2015. 
[4] H. Hens, G. Verbeeck, B. Verdonck, "Impact of Energy Efficiency Measures on the $\mathrm{CO}_{2}$ Emissions in the Residential Sector, A Large Scale Analysis," Energy and Buildings, c. 33, ss. 275$281,2001$.

[5] H. Bulut, O. Büyükalaca, T. Yılmaz, M. A. Aktacir, "GAP Bölgesi İçin Detaylı İklim Verileri," Harran Üniversitesi GAP IV. Mühendislik Kongresi Bildiriler Kitabl, ss. 183-191, Şanlıurfa, 2002.

[6] K. Papakostas, N. Kyriakis, "Heating and Cooling Degree-Hours for Athens and Thessaloniki, Greece," Renewable Energy, c. 30, ss. 1873-1880, 2005.

[7] JW. Lstiburek, "Hygrothermal Climate Regions, İnterior Climate Classes and Durability," Proceedings of the Eighth Conference on Building Science and Technology, Toronto, Canada, ss. 31929, 2001.

[8] N. Sahal, "Proposed Approach for Defining Climate Regions for Turkey Based on Annual Driving Rain İndex and Heating Degree-Days for Building Envelope Design," Building and Environment, c. 41, ss. 520-526, 2006.

[9] O. Büyükalaca, H. Bulut, T. Yılmaz, "Türkiye'nin Bazı İlleri İçin Derece Gün Değerleri," ULIBTK'99-023 12. Ulusal Isı Bilimi ve Tekniği Kongresi Sakarya, 8-10 Eylül 1999.

[10] M. Kocagül, Is1 İzolasyonında İdeal İzolasyon Malzemesi Kullanılmasının Deneysel Araştırılması, Yüksek Lisans Tezi, Elazı̆̆g: Firat Üniversitesi Fen Bilimleri Enstitüsü, 2013.

[11] N. Şişman, E. Kahya, N. Aras ve H. Aras, "Determination of Optimum İnsulation Thicknesses of the External Walls and Roof (ceiling) for Turkey's Different Degree-Day Regions," Energy Policy, c. 35 , s. 10, ss. 5151-5155, 2007.

[12] H. Moran, Farklı Derece Gün Bölgelerine Göre Optimum İzolasyon Kalınlığının YatırımTasarruf Yöntemine Göre Hesaplanması ve Çevresel Etki Analizi, Yüksek Lisans Tezi, Osmaniye: Osmaniye Korkut Ata Üniversitesi Fen Bilimleri Enstitüsü, 2018.

[13] B. Tanrıverdi, TS 825 2. Derece Gün Bölgesinde Yer Alan İllerin, Isıtma ve Soğutma Derece Gün Bölgelerine Göre Değerlendirilmesi, Yüksek Lisans Tezi, İstanbul: İstanbul Teknik Üniversitesi Enerji Enerji Enstitüsü, 2015.

[14] A. Ergün - T. Menlik - M. G. Özkaya, "Energy and Exergy Analyses of the Heating System in a Multipurpose Building," Gazi Mühendislik Bilimleri Dergisi, c.1, s.1, ss. 195-218, 2015.

[15] O. Büyükalaca ve H. Bulut, "Detailed Weather Data for the Provinces Covered by the Southeastern Anatolia Project(GAP) of Turkey," Applied Energy, s. 77, ss. 187-204, 2003.

[16] Düzce İl Kültür Ve Turizm Müdürlüğü Düzce İklimi Ve Bitki Örtüsü. [Çevrimiçi]. Erişim Adresi: http://duzcekultur.gov.tr/TR-211369/iklimi-ve-bitki-ortusu.html Erişim Tarihi: 12.12.2018

[17] Meteoroloji Genel Müdürlüğü. [Çevrimiçi]. Erişim Adresi: https://www.mgm.gov.tr/veridegerlendirme/il-ve-ilceler-istatistik.aspx?m=DUZCE

[18] S. Şensoy, R. Sağır, M. Eken, Y. Ulupınar, "Türkiye Uzun Yıllar Isıtma ve Soğutma Gün Dereceleri,” Devlet Meteoroloji İşleri Genel Müdürlügüu, Ankara, 2007.

[19] B. B. Ekici, A. Gülten ve U. T. Aksoy, "A Study on the Optimum Insulation Thicknesses of Various Types of External Walls With Respect to Different Materials, Fuels and Climate Zones in Turkey," Applied Energy, s. 92, ss. 211-217, 2012. 
[20] Ö. Kaynakl1, "Optimum Thermal İnsulation Thicknesses and Payback Periods for Building Walls in Turkey," Journal of Thermal Science and Technology, c. 33, ss. 45-55, 2013.

[21] A. Yıldız, G. Gürlek, M. Erkek ve N. Özbalta, "Economical and Environmental Analyses of Thermal Insulation Thickness in Buildings," Isl ve Bilim Tekniği , c. 28, s. 2, ss. 25-34, 2008.

[22] A. Bolattürk, "Optimum Insulation Thicknesses for Building Walls with to," Energy and Buildings, c. 43, ss. 1055-1064, 2008.

[23] Türkiye Cumhuriyeti Merkez Bankası, "Tüketici Fiyatları," [Çevrimiçi]. Erişim Adresi: http://www.tcmb.gov.tr/wps/wcm/connect/TR/TCMB+TR/Main+Menu/Istatistikler/Enflasyon+Veril eri/Tuketici+Fiyatları

[24] A.E. Gürel, Z. Cingiz, “Farklı Dış Duvar Yapıları İçin Optimum Isı İzolasyon Kalınlığı Tespitinin Ekonomik Analizi,” SAÜ. Fen Bilimleri Dergisi, c. 15, s.1, ss. 75-81, 2011. 